\title{
El hospital y la cofradía morisca de La Resurrección. ¿Fracaso o éxito de la política evangelizadora castellana?*
}

\section{The Hospital and the Morisco Brotherhood of the Resurrection. Failure or Success of the Castilian Evangelizing Policy?}

\author{
Amalia García-Pedraza \\ Archivo Histórico de Protocolos de Granada, Universidad de Granada \\ ORCID iD: https://orcid.org/0000-0002-8606-6849
}

\begin{abstract}
Resumen
El presente trabajo profundiza en el conocimiento del hospital y cofradía de La Resurrección, fundada por los moriscos del Albaicín (Granada). Utilizando documentación inédita del Archivo Histórico de Protocolos de Granada, del Archivo General de Simancas y del Archivo de la Alhambra, entre otros, se traza la historia de tan singular institución, apenas conocida a pesar de su proyección en el reino granadino y su supuesta participación en la Rebelión de 1568. Se presta especial atención al perfil social de sus cofrades, en su mayoría integrantes del grupo conocido como «los hombres ricos del Albaicín».
\end{abstract}

Palabras clave: Cofradía; moriscos; Granada; Andalucía; siglo XVI.

\section{Abstract}

This paper deepens the knowledge of the hospital and brotherhood of the Resurrection, founded by the moriscos of the Albaicín (Granada). Using unreleased documentation from the Historical Archive of Protocols of Granada, the General Archive of Simancas and the Archive of the Alhambra, among others, it traces the history of this institution, so unique, yet relatively unknown, despite its influence in the realm of Granada and its supposed participation in the 1568 rebellion. Special attention is paid to the social profile of the brotherhood members, also mostly members of the group known as "the rich men of the Albaicín".
\end{abstract}

Key words: Brotherhood; moriscos; Granada; Andalusia; sixteenth century.

Cómo citar / Citation: García-Pedraza, Amalia, "El hospital y la cofradía morisca de La Resurrección. ¿Fracaso o éxito de la política evangelizadora castellana?”, Al-Qanțara, 42, 2 (2021), e14. doi: https://doi.org/10.3989/alqantara.2021.011.

Recibido: 31/07/2020; Aceptado: 27/01/2021; Publicado: 10/12/2021

* Este trabajo se ha realizado bajo el marco del Proyecto I+D «La construcción de una cultura fiscal en Castilla: poderes, negociación y articulación social (ca.1250-1550)» (PG2018-097738-B-100), integrado en la Red Arca comunis. Financiado por el Ministerio de Economía, Industria y Competitividad del Gobierno de España. 


\section{Introducción}

Pocos años distaban del levantamiento morisco de las Alpujarras de $1568^{1}$, cuando Diego Hurtado de Mendoza daba cuenta de uno de los enclaves utilizados para gestar la confabulación conversa:

Teniendo el Rey y el prelado más respeto a Dios que al peligro, se les había concedido que hiciesen un hospital y cofradía de cristianos nuevos, que llamaron de la Resurrección (...) En días señalados concurrían en el hospital a tratar de su rebelión con esta cubierta ${ }^{2}$.

La densidad informativa de este escueto párrafo es indiscutible. En apenas cuatro líneas se nos revela la existencia, en la capital del reino, de una cofradía de cristianos nuevos, vinculada a un hospital, cuya fundación contó con el beneplácito de las autoridades religiosas y de la propia Corona. Iniciativa que sin duda buscaba reactivar la política evangelizadora que inaugurara Talavera, impulsara con rigor Cisneros y mantuvieran, con mayor o menor acierto, los sucesivos prelados que ocuparon la sede granadina $^{3}$. Sin embargo, a tenor de la última frase de Hurtado de Mendoza, tan ambiciosa apuesta no solo fue fallida sino contraproducente. Lejos de afianzar su cristianismo, la cofradía fue la cortina de humo que permitió a los moriscos granadinos organizar impunemente su rebelión. Un alzamiento que enarboló la bandera del islam desde su inicio, prueba irrefutable del fracaso de décadas de evangelización y aculturación ${ }^{4}$.

La rebelión de los cristianos nuevos del reino de Granada, de 1568, revistió una gravedad que superó el marco local. El alzamiento implicó la traición de una parte de los súbditos de la Corona a su rey y al orden establecido, a la par que un ataque directo a la Iglesia y a la fe católica. Esta gravedad es una de las razones que explica por qué un suceso puntual, restringido a un área del reino de Castilla, tuvo tanta repercusión, siendo capaz de generar, como apunta Javier Castillo refiriéndose a las tres crónicas que analizaron la Guerra de Granada, «una trilogía de tal diversidad y calidad histórica y literaria, solo comparable al amplio ciclo de los cronistas del Indias». Mármol, Historia, p. XXX.

2 Hurtado, Guerra de Granada, p. 218.

3 Son numerosos los autores que defienden que la labor evangelizadora de Cisneros, sin duda más dura en los métodos, no fue antagónica a la de Talavera. Por el contrario, como ya apuntara Garrido Aranda, la política religiosa del fraile jerónimo anticipó, «en cierto sentido, la reforma iniciada por Cisneros». Garrido Aranda, Organización de la Iglesia en el Reino de Granada, p. 66.

4 No obstante, más allá del tema religioso, Hurtado de Mendoza fue consciente de la complejidad del problema morisco y de la propia sociedad cristiana en la que se insertó la minoría. De ahí que en su obra no se limite únicamente a
Fundamentada o no, la inculpación directa y sin matices de los cofrades de La Resurrección en la trama de la rebelión, así como la visión del hospital como refugio de conspiradores, sería secundada por otro de los tres cronistas de la rebelión: Ginés Pérez de Hita ${ }^{5}$. Con un relato más prolijo en detalles, aunque erróneo en la identificación del hospital ${ }^{6}$, este autor apunta a la pragmática de 1566 como el detonante de la confabulación:

Habiéndose pregonado pues que los moriscos de Granada dejasen lengua y hábito, luego todo el reino fue alborotado, y quedó malcontento de tal mandamiento; y así los más principales de la tierra se comunicaron sobre lo que harían en este caso. Después de haber tratado muchas cosas sobre ello (...) acordaron levantarse y tomar armas.

denunciar la traición de los conversos granadinos, sino que también reproche la dura política contrarreformista filipina, a la vez que recoge los conflictos políticos que el levantamiento alpujarreño ayudó a escenificar: el enfrentamiento entre ebolistas y albistas; la pugna por ocupar espacios de poder entre la aristocracia feudal andaluza y el nuevo cuerpo de letrados que respaldaba la Corona. Varo Zafra, "Carta de don Diego Hurtado de Mendoza al Cardenal Espinosa".

5 Ginés, La Guerra. Sobre el tema analizado, conviene subrayar que junto a Hurtado de Mendoza y Ginés Pérez de Hita, el tercer cronista de la Guerra de la Alpujarra, Luis del Mármol Carvajal, sin duda el más veraz y mejor informado de los tres, guarda sobre La Resurrección y sus cofrades un sospechoso silencio. De hecho, a lo largo de su obra, no los cita nunca. No obstante, es revelador que sí denuncie abiertamente, como promotores de la rebelión, a los hombres ricos del Albaicín. Hombres que tras la pragmática de 1566: «... acordaron que sería bien hacer con los moriscos de la Alpujarra que tratasen de levantarse...porque el principal intento de los hombres ricos del Albayzin no era que hubiese rebelión general, ni que entrasen berberiscos en la tierra, ni querían ser sujetos a rey moro... solamente querían estarse como estaban y hacer su negocio con peligro de cabezas ajenas». Su mención de los «hombres ricos del Albaicín» guarda una conexión directa con La Resurrección, pues como más adelante se mostrará, un número importante de ellos integraron las filas de la cofradía que regentaba el hospital. Mármol, Historia, p. 157.

6 Según Ginés, el hospital que idearon como «tapadera», estuvo destinado a curar a «los moriscos pobres enfermos del mal de lepra». Razón por la que el edificio se ubicaría «en San Lázaro fuera de la ciudad, camino de Albolote». Pero estas referencias no coinciden con el hospital de La Resurrección, fundado por los moriscos del Albaicín y situado en la plaza de Bibalbonut. Tal vez la confusión se deba a que bajo la protección de los Reyes Católicos, fray Hernando de Talavera fundó un hospital para leprosos, llamado San Lázaro, que acogió a «moros con diversas enfermedades que entonces se agrupaban con el título común de lepra». Hospital cuya primera ubicación parece que fue la misma plaza. Vega García-Ferrer, Fray Hernando de Talavera y Granada, p. 83. Algunas noticias sobre ambos hospitales pueden seguirse también en Fernández, Fray Hernando de Talavera, confesor de los Reyes Católicos; López Guzmán, Tradición y clasicismo en la Granada del XVI; Barrios Rozua, Guía de la Granada desaparecida. 
La contundencia de la respuesta acordada a los planes regios diseñados para aniquilar cualquier seña de identidad musulmana, requería previamente planificar cuándo, dónde $\mathrm{y}$ cómo darla. Pero, antes que nada, urgía saber si era factible o no, es decir, si se contaba con suficientes efectivos de hombres y armas para llevar a cabo, con éxito, el levantamiento. Y es aquí donde entra en escena La Resurrección:

habiéndose comunicado los más poderosos del reino, fue acordado que se hiciese alarde de la gente de guerra que podía haber en él, y esto fuese con tal secreto, que de nadie fuera entendido, para lo cual se dio en una diabólica astucia, y fue pedir a la ciudad de Granada licencia para hacer un hospital muy grande, en donde fuesen curados los moriscos pobres enfermos $(\ldots)$ dieron orden con cartas y permiso del provisor, que era el doctor Román, grande hombre en letras, para que fuesen dos moriscos por todo el reino y por todas las Alpujarras a pedir limosna para la obra de aquel hospital. Y el orden que en esto se llevaba era que la casa en que había dos hombres de pelea diese dos cuartos, y donde uno, uno; deste modo, según el número de hombres que había en cada casa, así se daban los cuartos; y por este secreto ardid, contando los cuartos se halló que habría cuarenta y cinco mil hombres de pelea $(. . .)^{7}$

Idéntica línea argumental la hallamos en los autores de distintas Historias sobre la ciudad, todas publicadas a lo largo de la centuria del seiscientos $^{8}$. Entre ellos cobra notoriedad Antolinez

7 Coincide Pérez de Hita con Hurtado de Mendoza en su denuncia de La Resurrección como correa de transmisión de los planes de rebelión entre los moriscos del reino, a la vez que medio para conocer el potencial humano con el que se podía contar. Por el contrario, Luis del Mármol Carvajal señala el empleo de otro ardid para este último fin: el conocimiento que proporcionaban los padrones de la farda: «Y exagerando la sujeción que tenían, les traían a la memoria sus fuerzas diciendo que habia ochenta y cinco mil casas de moriscos empadronadas para farda en el Reino de Granada, sin otras más de quince mil que encubrian los repartidores». Mármol, Historia, p. 156. Sumamente interesante resulta comprobar como Pedro de Valencia, ya en relación a los moriscos expulsados del Reino, muestra su temor de que éstos se valgan del mismo recurso para conspirar de nuevo contra el rey. Alertando del peligro que supone permitirles confeccionar «lista, y padrón del número de casas y personas que tienen en el Reyno», advierte: «dicen que para que repartan entre si las cargas de los tributos con igualdad que les tocan; este es el pretexto, pero quién les quita que lo hagan ellos principalmente para saber sus fuerzas y dar aviso de ellas al turco y a los reyes de África». Citado por Pérez García y Fernández Chaves, Las élites moriscas, p. 165.

8 Sin duda, los dos autores más importantes de este tipo de Historias locales fueron Francisco Bermúdez de Pedraza, Antigüedad y Excelencias de Granada, y Francisco Henríquez de Jorquera, Anales de Granada: descripción del reino y ciudad de Burgos, cuyo testimonio adquiere un valor añadido por haber sido el encargado de gestionar, en 1609, como contador mayor de las iglesias del arzobispado, el arrendamiento del hospital de La Resurrección a los Niños de la Doctrina9:

(...) viendo la necesidad que tenían de juntarse y la dificultad que para esto avía, por estarles vedadas cualquier género de juntas, trataron de hazer en el Albaizín un hospital y hermandad, so color de curar los pobres de su nación. Diéronles licencia para hazelle. Hiziéronle, con el título de La Resurrección (nombre equívoco entre ellos, entendiendo por él la que pensavan tener de la sugección a la libertad que por este medio creyan alcanzar); y éste les sirvió de cubierta para tratar su rebelión ${ }^{10}$.

Finalmente, como último ejemplo del tratamiento historiográfico dispensado a La Resurrección, cabe citar al jesuita Juan de Santibáñez. En su Historia de la Compañía de Jesús en Andalucía, el religioso identifica sin ambages la aspiración última de los rebelados, el motivo real que les animó a erigir una cofradía de conversos del islam en Granada: poner de nuevo a España bajo el dominio musulmán:

color de piedad los juntava en çierto hospital (donde oi es convento de frailes Agustinos descalços) a tratar de el remedio de los neçesitados i pobres. No se tratava allí sino de envestir a los descuidados i de poner otra vez aquel reyno y aun España debajo del jugo mahometano ${ }^{11}$

de Granada, crónica de la reconquista (1482-1492), sucesos de los años 1588 a 1646. Ambos imprescindibles para comprender el período histórico en el que nace La Resurrección.

9 El 24 de diciembre de 1609, siguiendo las directrices del Arzobispo granadino, Antolinez de Burgos quedó a cargo de arrendar el hospital "general que está en el Albaizín, en la plaça de Bibalbonut, para que biban y se recogan en él los niños de la doctrina». Como arcediano de la Iglesia granadina y provisor y contador mayor de las iglesias del arzobispado, Antolinez firmará un arrendamiento por cuatro años, a razón de 22 ducados anuales. Archivo Histórico Diocesano de Granada (en adelante AHPDGr), Contaduría, legajo 330F, s.f. Con anterioridad, el licenciado Alonso Román, canónigo de la Iglesia del Salvador, en nombre del Arzobispo Juan Méndez de Salvatierra, había arrendado a don Diego de Loaisa, Abad de la Colegial del Salvador, «El hospital que dizen del Albayzin questa junto y a linde de la plaça de Bibalbonud del dicho Albayzin que alinda con la muralla e con casas de su magestad». Lo arrienda por tiempo de un año, a razón de 8 reales de plata cada mes. En la escritura aparece recogida la entrega al abad de la llave del postigo de la puerta principal, especificando que el resto de llaves y cerrojos que necesite el hospital se harán a costa de la renta. Archivo Histórico de Protocolos de Granada, (AHPrGr); G-224, fol. 282r/v.

10 Antolínez de Burgos, Historia eclesiástica de Granada, p. 255.

11 Santibáñez, Historia de la Provincia de Andalucía, p. 110. 
Tras la publicación de estas Historias, resulta paradójico observar el mutismo generalizado que sobre La Resurrección han guardado las sucesivas generaciones de historiadores. Y ello pese al protagonismo concedido al hospital en un episodio clave para la historia de la minoría. Un largo silencio interrumpido por menciones puntuales en trabajos monográficos sobre los moriscos, como el de Julio Caro Baroja ${ }^{12}$, en algunas guías histórico-artísticas de la ciudad ${ }^{13}$, o en trabajos sobre hospitalidad nazarí1 ${ }^{14}$. Ni siquiera la eclosión bibliográfica sobre el antiguo reino de Granada, producida en los años ochenta del siglo pasado, rescató su historia. De hecho, el primer trabajo - y el único hasta el momento- que abordó con más profundidad la actividad del hospital y la cofradía que lo rigió, dando noticias inéditas sobre ambos a partir de fuentes de archivo, data de $2002^{15}$. Años después, en 2007, siguiendo la estela de las guías artísticas de la ciudad, el hospital volvió a ser objeto de atención en una tesis sobre la arquitectura asistencial en Granada ${ }^{16}$.

12 Julio Caro Baroja, en su ya clásica obra sobre los moriscos granadinos, siguiendo la estela de Hurtado de Mendoza, ratifica el carácter conspiratorio de La Resurrección: «la morosidad de la burocracia de Felipe II permitió a los moriscos llevar a cabo ciertos preparativos. La pragmática se había publicado el 1 de enero de 1567 ...Hasta las navidades de 1568 todos fueron cábalas, gestiones y conspiraciones. Tenían los moriscos en Granada un hospital y cofradía de La Resurrección y en los locales de aquél se reunían, no tanto para practicar la piedad como para darse noticias y proyectar». Caro Baroja, Los moriscos del Reino de Granada, pp. 172-173.

13 Gómez-Moreno, Guía de Granada. Antonio Gallego y Burín, en su guía artística e histórica de la ciudad, refiere escuetamente la ubicación del hospital: «A la izquierda de la plaza (se refiere a la de Bibalbonud) existió el Hospital general de moriscos, llamado de La Resurrección, donado a la ciudad después de dicho alzamiento». Gallego y Burín, Granada. Guía Artística e Histórica de la Ciudad, p. 522. Décadas después, en un documentado trabajo sobre el urbanismo granadino, Rafael López Guzmán vuelve a recapitular los pocos datos conocidos sobre el hospital en su libro Tradición y clasicismo.

14 García Granados, Girón Irueste y Salvatierra Cuenca, El Maristán de Granada.

15 Ese año veía la luz mi tesis doctoral, trabajo que tenía entre otros objetivos el de analizar al colectivo converso teniendo muy en cuenta los datos derivados del análisis sistemático de los protocolos notariales. Una fuente que me dio la oportunidad de consultar testimonios directos generados por la propia cofradía y hospital. La tesis fue publicada un año después de su defensa. García Pedraza, Actitudes ante la muerte en la Granada del siglo XVI.

16 Esta interesante tesis, aún sin publicar, no aporta apenas nada en relación al hospital de La Resurrección, excepto la referencia a tres documentos procedentes del Instituto Gómez-Moreno. La información que arrojan sobre él va referida a los años posteriores al levantamiento morisco, cuando el hospital dependía ya del arzobispado. Cambil Hernández, $L a$ arquitectura asistencial en Granada.
Es evidente que La Resurrección sigue siendo una incógnita. De hecho, las circunstancias que rodearon su propio nacimiento plantean serias dudas. ¿Se trató de una refundación del antiguo hospital General de Moriscos? o, por el contrario, ¿estamos ante una institución nacida de nuevo cuño y con edificio propio ${ }^{17}$. Pero creado o refundado, y al margen de su posible implicación en los sucesos de 1568, su mera existencia debería haber sido objeto de una investigación detallada.

\section{Un origen incierto, una trayectoria apenas conocida, un final trágico}

Si tuviésemos que fijar la fecha de nacimiento del hospital «del Albayzin (...) que se nonbra de la Santa Resureçión de Nuestro Redentor Ihesu Christo» ${ }^{18}$, partiendo de las noticias contenidas en las crónicas de la Guerra de las Alpujarras, dataríamos su creación en 1566. Año en el que se promulgó la pragmática que prohibía, ya con carácter definitivo e irreversible, cualquier manifestación cultural de la minoría ${ }^{19}$. Sin embargo, distintos documentos sitúan su fundación a finales de la década de los cincuenta. Entre ellos se puede citar el testimonio que nos proporciona Francisco Oçul en su testamento. Redactado el 6 de julio de 1567, en una de sus mandas recordaba como:

Puede aver honze años, poco más tiempo, que los hermanos e cofrades del dicho ospital me han tenido en el dicho hospital, por ser como soy onbre viejo y enfermo, e no thener muger ni hijos, ni aver sido casado. E me han dado todo el dicho tiempo de comer e bever e vestuario, y lo que he avido menester ${ }^{20}$.

El recuerdo de Oçul parece fidedigno. El 21 de enero de 1558, Beatriz Mogabara mandaba «para el ospital que nuevamente se a hecho en el Albayzín desta çibdad, para ayuda a curar los enfermos dél, vn ducado en limosna ${ }^{21}$. Tes-

17 Hasta la fecha, salvo en mi libro Actitudes ante la muerte en la Granada del siglo XVI, los trabajos que abordan el tema siguen los textos de Henríquez de Jorquera o Bermúdez de Pedraza, quienes mencionan un único hospital: el Hospital General de moriscos. Según estos autores, este hospital pasaría a llamarse en época morisca de «La Resurrección».

18 Así se le cita en una carta de pago fechada el 2 de mayo de 1562. AHPrGr; G-125, fol. 492r.

19 Esta vinculación directa se puede observar en la obra Pérez de Hita, La Guerra de los moriscos, p. 4.

20 AHPrGr; G-158, fol.790v.

21 AHPrGr; G-106; fol. 85r. En el mismo protocolo contamos con otro testimonio, esta vez datado el 9 de marzo de 1558. Se trata de Andrés Yaçin, regador, quien consigna en una cláusula de su testamento una limosna 10 ducados al hospital. Dinero destinado a ayudarles a «curar los pobres y enfermos dél». Fol. 233r. 
timonios al que se unen otros que avalarían el funcionamiento del hospital en la década de los cincuenta, aunque probablemente no se hubiese finalizado su construcción. Tal vez ocupaba por estas fechas una sede provisional. Diego el Comayhi, mercader y vecino del Salvador, nos pone sobre aviso de esta posibilidad:

Yten mando que de mis bienes se saquen diez ducados de oro, los quales se den al tienpo que se oviere de labrar y edificar el Ospital que nuevamente se a hecho en el Albayzin (...) E mis albaceas, en el entre tanto que no se labrare, los tengan en depósito para los distribuyr e gastar por sus manos en la labor del dicho ospital y en el tiempo que les paresçiere gastarlos, estando labrándose ${ }^{22}$

Fuesen cuales fuesen sus inicios cronológicos, es indudable que la década de los años sesenta se inauguró con un hospital y cofradía de moriscos en pleno funcionamiento. Hecho que ratifica la carta de poder suscrita en 23 de enero de 1560 por los «hermanos del dicho ospital», quienes confían a Lope de Padilla Abenhalafe «pedir e demandar, reçebir e aber e cobrar (...)de quales quier personas (...) los maravedies, e bienes muebles e raizes, e otras cosas, que asta oy obieren dado o mandado de limosna» ${ }^{23}$.

Menos dudas que su fecha de erección ${ }^{24}$ arroja la función que cumplió desde su aparición en escena: «recoger, curar e sustentar enfermos» ${ }^{25}$. Todo apunta a que la cofradía, perfectamente organizada, con una jerarquización y articulación

22 El testamento está fechado el 20 de diciembre de 1559 AHPrGr; G-111, fols.1105r/1109v. Meses antes, un morisco tan destacado como Luis Hernández, hijo de Isabel Çaybona, y uno de los repartidores al por mayor de los servicios moriscos, lega al hospital 6 ducados de oro. El dinero se entregará al mayordomo del hospital «al tiempo que se quisiere labrar e hizieren en él labor y no antes». AHPrGr; G-111, fols. 625r/628v.

${ }_{23}$ AHPrGr; G-115, fol. 102r/v.

24 Duda, en primer lugar, porque no contamos por el momento con un documento fundacional de la cofradía. En segundo lugar, porque existen otras referencias documentales que contradicen los testimonios de Oçul y Mogabara. Por ejemplo, el rico mercader Francisco el Caçar, en el testamento que otorgó el 10 de enero de 1563, documento que muestra su magnanimidad con La Resurrección, manifiesta su deseo de contar con la cofradía en su cortejo, aclarando seguidamente: «si al tiempo de mi fallesçimiento estuviere fundada». En caso contrario, establece que lo acompañe la cofradía sacramental del Salvador. AHPrGr; G-131, fol. 51r/v.

25 Así lo señalaba en su carta de donación Bartolomé Abli, vecino de Armilla, quien cedía al hospital ocho fanegas de tierras de secano. Abli daba de esta forma cumplimiento al deseo manifestado por su madre de ayudar «a los gastos que en el dicho ospital se hacen cada día de recoger, curar e sustentar enfermos». AHPrGr; G-159, fol.153r. de sus cargos idéntica a la de cualquier otra cofradía cristiano vieja, desplegó una labor asistencial eficaz, centralizada y dirigida desde el hospital construido en la plaza de Bibalbonud ${ }^{26}$. Para ello contó con personal cualificado que cubrió el cuidado físico de los enfermos, haciendo suyas las palabras predicadas por fray Hernando de Talavera:

Traya el continuo estas palabras en la boca. Quid iuuat infirmos visitare, nisi eis aliquid praestemus obsequii.Y dezía gran verdad porque, cierto, aprovecha poco visitar al enfermo, si por alguna manera no le ayudaramos a passar su enfermedad o su pobreza $^{27}$.

La asistencia médica dispensada a los enfermos acogidos debió de ser completa. Es lo que se deduce de la donación de Catalina Abiza al hospital, en 1562. Entregándole algunos de sus enseres domésticos, esta mujer quiso agradecer que la mantuviese «asi en lo ordinario, como físico, mediçinas, e otras buenas obras» ${ }^{28}$. Un físico que tal vez fuese el licenciado Pedro de Piñar, médico que firmó como testigo en los testamentos otorgados por algunos de los enfermos ingresados. Papel que también desempeñó en múltiples ocasiones el cirujano Francisco de Santa Cruz el Hamil $^{29}$. Junto a estos profesionales cualificados, el hospital contó con personal de apoyo, tal y como nos descubre la declaración del matrimonio compuesto por Alonso de Carrión y Gracia de Madrid, enfermeros que mantuvieron con la cofradía una relación que excedió el ámbito de lo estrictamente laboral ${ }^{30}$.

26 La construcción del inmueble debió financiarse gracias a las donaciones de los moriscos del Albaicín. Sirva de ejemplo la manda incluida en el testamento del mercader Diego el Comayhí, vecino del Salvador: «...que de mis bienes se saquen diez ducados de oro los cuales se den al tiempo que se oviere de labrar y edificar el hospital que nuevamente se a hecho en el Albayzin». AHPrGr, G-111, fol.1105v.

27 Vega García-Ferrer, Fray Hernando de Talavera, p. 182.

28 Testamento de Catalina Abiza. AHPrGr, G-158, fol.897r.

29 AHPrGr; G-131, fol.1167r.

30 En una carta de finiquito datada el 4 de agosto de 1567 , Alonso de Carrión, enfermero, declara haber trabajado para el hospital desde el 29 de abril de 1566 hasta el 3 de agosto de 1567. Recibió por ello 25 ducados. A su esposa Gracia, quien había trabajado en el hospital nueve meses, se le entregaron 4 ducados en concepto de salario. Pero antes de firmar esta escritura de finiquito, ese mismo día Alonso de Carrión firmó otra escritura notarial. Esta vez para finiquitar los veinte ducados que le debía el hospital desde el 17 de febrero de 1567. Fecha en la que prestó a La Resurrección ese dinero «para çiertos socorros e para pagar çiertas devdas por la hazienda de don Fernando Muley que el dicho ospital avía de aver». AHPrGr; G-158, fols.884r/ 886r. Efectivamente, con fecha 17 de febrero 
Pero no solo se preocupó el hospital de reclutar personal cualificado. Dotarse de una infraestructura adecuada a las necesidades de los enfermos fue otra de sus prioridades. Así, en 1562, solicitó al consistorio granadino un permiso de obras para construir un pilar que les abasteciera de agua:

El dicho hospital y proves del padecían estrema neçesidad de agua para su seruiçio y linpieza. Y que junto a él está un caño de agua que esta çiudad mandó poner junto a él, en la plaça de Bibaalbolut, de las aguas que traxo de las fuentes de Valdelparyso, y que el remanente de la dicha pila va perdido sin que del se aprouechase persona ninguna. Que nos suplicauan y pedían por merced, le diesemos el dicho remanente al dicho hospital para el dicho efecto, y que se ofrecían a lo dar cada questa çiudad lo oviese menester para poner en algún edifiçio público. $Y$ ansí mismo, a su costa, harán en lugar del dicho caño vn pilar en la dicha plaça de Bibaalbolut, que quede por público para esta çiudad en reconpensa de aquesta merced que piden ${ }^{31}$.

En relación a la asistencia espiritual, labor fundamental en la concepción hospitalaria europea de la época, La Resurrección debió seguir, en principio, el mismo patrón de los hospitales cristianos. De entrada, tuvo cementerio propio. Un espacio sagrado que, con el paso del tiempo, se vio ampliado gracias a la generosidad de vecinos como Juan Alonso de Baena, un tejedor de terciopelo afincado en el Salvador que donó, en 1566, parte de un:

(...) corral, que será de quatro varas de largo e vara e media en ancho, poco más o menos (...) porque el dicho quiere hazer vn çimenterio para sepultar en él los difuntos del dicho hospital, y el sitio que

de 1567, La Resurrección había suscrito con el enfermero una escritura de obligación. Gracias a ella sabemos que la cofradía y hospital fueron los herederos de don Hernando Muley. Razón por la que debieron hacerse cargo de sus deudas, entre las que se contaban los veinte ducados que don Hernando debía a la mesa capitular de la ciudad. AHPrGr; G-158, fol. 199r/v.

31 Vista la petición, el cabildo nombra a don Francisco el Zegri, veinticuatro de la ciudad, y a Francisco de la Cuevas, jurado, para que informen sobre la conveniencia de autorizar su construcción. El parecer de ambos es favorable, siendo su opinión avalada por los alarifes. El cabildo da su autorización para emprender las obras, aunque estas deberían respetar ciertas condiciones, entre ellas hacer: «el pilar y pila y allanada la dicha plaça...encañar y lleuar y guiar al dicho hospital». Asimismo, les exige que «no la pueda vender todo ni parte della a ninguna persona...sin liçençia ni consentimiento». El 21 de marzo de 1566, Lorenzo Hernández, vecino de San Miguel, como prioste, y Miguel López Arroba, como mayordomo de La Resurrección, aceptan y se obligan a edificar el pilar y pila, aceptando que «quede por hedifiçio público y conçejil desta ciudad». Este documento se encuentra en el AHPrGr, G-109, fols. 12r/14r. para ello tienen es angosto. E para que se ensanche algund tanto, mi voluntad es de hazer donación al dicho hospital del dicho pedaço de corral $(\ldots)^{32}$.

También contó con alguna dependencia destinada al culto divino y a los oficios de la cofradía. No olvidemos que estas asociaciones de laicos tenían, entre otras funciones, la de interceder mediante las oraciones por las almas de los difuntos y participar en los cortejos fúnebres. La Resurrección cumplió ambas, como consta por múltiples testimonios. Uno de ellos nos lo proporciona Lázaro Albeytar, mercader que en su cortejo solicitó a «la cofradía y hermandad del ospital que nuevamente se a fecho y fundado (...) con su çera y con la cruz que la dicha cofradía tiene» ${ }^{33}$. Otro nos lo reporta el geliz de la seda, Gonzalo Fernández el Comaxaxa, quien donó un censo de veinte ducados al año, destinado no solo al mantenimiento de los enfermos, sino también a pagar las oraciones que por él dijeran los cofrades «porque los dichos cofrades tengan cuidado de rogar a Dios por mi ánima $»^{34}$.

Más difícil resulta dilucidar si la dotación de bienes muebles y objetos para las celebraciones fue similar a la de otras cofradías o si tuvo, por el contrario, algún rasgo diferenciador. Una incógnita por el momento difícil de despejar. De hecho, no se puede establecer el origen de las piezas detalladas en el inventario que ordenó hacer, en 1582, el arzobispo Juan Méndez de Salvatierra, cuando "atento que, en el hospital de la Resureçión, que está en el Aluaizin desta çiudad, no se haçía hospitalidad ninguna», ordeno que sus bienes "se diesen y repartiesen para el seruiçio de las iglesias deste arzobispado».

El reparto requirió la elaboración previa de un inventario ${ }^{35}$ :

Primeramente, un cajón de madera con dos gauetas a los lados y sus çerraduras, sin llaues, donde se solía dezir misa. Un dosel de guadameçil vie-

32 AHPrGr, G-147, fol. 581r.

33 AHPrGr; G-112, fol. $1675 \mathrm{v}$.

34 AHPrGr; G-112, fols. 1209r/1219v.

35 Este documento se halla en el AHDGr, Contaduría, legajo $330 \mathrm{~F}$, pieza 1, s.f. Una transcripción del inventario se puede consultar en la tesis doctoral de Cambil Hernández, $L a$ Arquitectura asistencial, p. 5 y p. 381 . Aunque conviene aclarar que la transcripción que reproduce esta autora no corresponde al original, sino que recoge la realizada por Manuel Gómez-Moreno, conservada en la actualidad en la Fundación Rodríguez Acosta. La transcripción que se ofrece en este artículo se ha realizado sobre el documento original. 
jo, y en medio una ymajen de la Coronación de Nuestra Señora de pinzel. Un frontalviejo de guadameçil para el dicho caxon. Unas andas grandes de madera. Un atrillo para el coro. Un cubilete para el altar. Lo qual se dio para el seruiçio de la Iglesia de Guejar.

\section{[Al margen: a las Albuñuelas]}

Yten, una cruz grande de madera labrada de talla dorada, a una parte un Christo de bulto de la Resureçión, y de la otra parte Nuestra Señora. La qual se dio para el seruiçio de la yglesia de Buñuelas del Valle.

\section{[Al margen: a San Salvador]}

Yten, dos vancos de madera, uno grande nuevo y el otro mediano, y unas palabras de la consagración, y un façistor, y un atril para dezir misa, lo qual se dio para la yglesia de Sant Saluador. Y una ymajen de Nuestra Señora, de Bulto, que se puso en la puerta pequeña de la dicha Yglesia ${ }^{36}$.

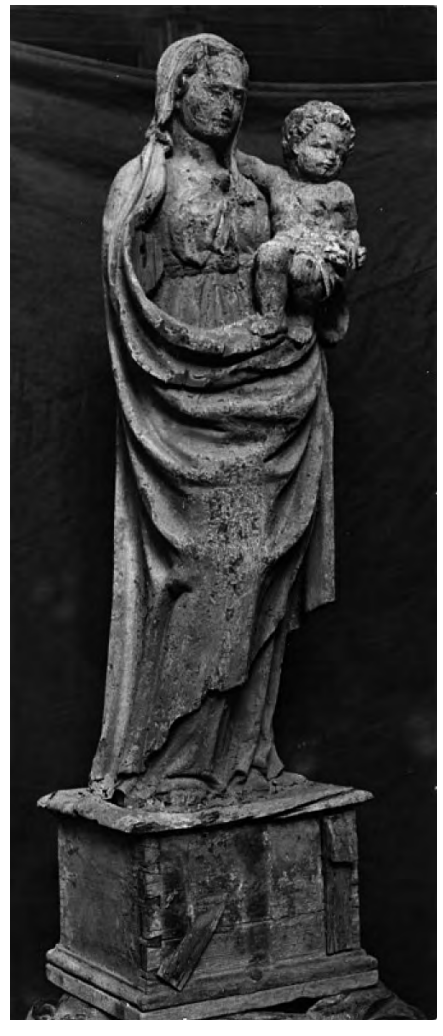

Virgen con el Niño

36 Esta escultura de «Nuestra Señora, de bulto», aún permanecía en la portada de la iglesia del Salvador cuando Gómez-Moreno escribió su Guía de Granada, en 1892. Don Manuel la describía en los siguientes términos: «la hornacina contiene una pequeña imagen de madera, que representa a Ntra. Sra. y estuvo en el inmediato Hospital General». Gómez-Moreno, Guía de Granada, p. 478. Agradezco sinceramente al conservador de la Fundación Rodríguez Acosta, Javier Moya Morales, la gran ayuda que me ha prestado para localizar las imágenes que de la obra se reproducen en este trabajo, así como agradezco a la citada Fundación que me autorizara a reproducirlas.
El desmantelamiento de la iglesia no debe hacernos pensar en un cese total de la labor asistencial llevada a cabo en el inmueble. Por el contrario, «la dicha casa y hospital se a señalado para recoger generalmente todos los pobres mendigantes que andauan por esta çiudad». Decisión que obligó al arzobispo a redecorar la iglesia para seguir celebrando misa. Iniciativa que conllevará el encargo de una obra a Pedro de Raxis, como consta por la libranza de pago que se le hizo el 18 de junio de 1582:

(...) en el maestro Juan de Solis, tesorero general de las iglesias deste arzobispado, se libraron a Hernando de Origuela, guadameçelero, y Pedro de Raxis, pintor, tresçientos y sesenta reales, que los huuieron de auer. Al dicho Origuela, çiento y quarenta reales por raçón de setenta pieças de guadameçel dorado, que entraron en un dosel con su çielo que hizo para el seruiçio deste dicho hospital general. Y los doçientos y veinte reales al dicho Pedro de Raxis, por razón de la pintura e historias que lleuaba el dicho dosel ${ }^{37}$.

$\mathrm{Si}$ a estos testimonios unimos la escritura de obligación, suscrita el 20 de febrero de 1582 por Rodrigo Alonso de Mesa, haciéndose cargo de la panadería del hospital ${ }^{38}$, se puede aventurar que el edificio - siempre bajo el control directo del arzobispado - prestó labores asistenciales hasta finales del siglo XVI. No obstante, es difícil establecer si lo hizo de forma continuada ${ }^{39}$. Ya en los inicios del siglo XVII, el inmueble se destinará a otro fin: los niños de la doctrina ${ }^{40}$. Un uso que pronto se vio truncado por la decisión regia

37 Gracias a la tasación que de la obra de Raxis hace otro pintor, Tomás de [Baltana], conocemos el tema desarrollado en su pintura: «e bisto la pintura de Christo con Juan y María, y dos historias, vna del rico abariento y otra del señor [Abrahan,] $y$ dos escudos de armas de su Ylustrísima señoría». La pintura será valorará en 20 ducados. AHDGr; Contaduría, legajo 330 F, pieza 1, s.f.

38 En la escritura el hospital se designa como «de los proves». Pero en el margen izquierdo, una anotación lo designa como «del Albaicín». AHPrGr; G-240, s.f.

39 El 30 de octubre de 1579, Alonso Romano, canónigo de la iglesia colegial del Salvador, en nombre del arzobispo Méndez de Salvatierra, arrienda a don Diego de Loaysa, colegial del Salvador, «el ospital que dizen del Albayzin, que está junto y a linde de la plaza de Bibalbonut del dicho Albayzin, que alinda con la muralla y con casas de su magestad». Sin especificar para qué, el arrendamiento fue por un año, a razón de cuatro reales al mes. AHPrGr; G-242; fol. 282r/v.

40 Antolínez de Burgos, provisor y contador mayor de las iglesias del arzobispado de Granada, ordenó a Martín de Soto, maestro de Albañilería, el arrendamiento del hospital por cuatro años y veinte dos ducados anuales de renta. AHDGr; legajo $333 \mathrm{~F} / 2(1)$. 
de ceder el inmueble a los Agustinos Descalzos para que estableciesen en él su convento.

Pero si sobre su fundación y trayectoria vital aún planean interrogantes, no así sobre los motivos que llevaron a su clausura en 1568. La narración de fray Pedro de Jesús es clara al respecto «(...) se les avía confiscado por el levantamiento que hizieron el año de 1568$\rangle^{41}$. Trágico final que intuyeron los cofrades e intentaron evitar. El 14 de noviembre de ese fatídico año, con el propósito de no ser objeto de ninguna controversia, buscando acallar rumores y pasar desapercibidos, requirieron a Alonso de León Majagual que dejase de pedir limosna en nombre del hospital:

Solia yr a la tierra de Granada, e otras partes, a pedir limosna para el dicho hospital e pobres dél. E porque entre los hermanos del dicho hospital e oficiales del, e el dicho prioste, está tratado e platicado quel dicho Alonso de León, de aquí adelante, no pida ni demande, en nonbre ni para el dicho hospital, limosna ninguna en esta çib$d a d$, ni fuera della, ni otras partes, por çiertos ynconvinientes que al dicho hospital se le sigue, e porque conviene así al onor del dicho hospital e cofrades del, e por otras cabsas que para ello les han movido ${ }^{42}$.

El párrafo nos deja entrever un ambiente crispado, en el que la actividad de La Resurrección es vista con recelo por los cristianos viejos. Y ello a pesar de las claras conexiones que existían entre la cofradía y la Iglesia. De hecho, la revocación del poder contó entre sus testigos con los jesuitas Albotodo y Sancho de Ceballos. Este último morirá, apenas un año después, en la provincia de Axacán, en la costa de Florida, a manos de los mismos indígenas a los que debía adoctrinar ${ }^{43}$, en una misión que le fue encomendada dada su experiencia con los moriscos del Albaicín. Un contacto jesuitas-moriscos no conocido con la profundidad que merece el tema ${ }^{44}$ y que, en relación a la

${ }^{41}$ Fray Pedro de Jesús, Templo Nuevo de los Agustinos Descalzos de Granada, p. 30.

42 AHPrGr, G-159; fol. 1281r/v.

43 Así lo cita Santibáñez, en su obra Centurias. Elogios de varones ilustres de la Provincia de Andalucia, Centuria I, núm. 61 y 62. Agradezco a Julián Lozano el que me haya facilitado este dato.

44 Los protocolos notariales conservan ejemplos ilustrativos de este estrecho contacto entre minoría y jesuitas. Por ejemplo, sabemos que la escuela que los jesuitas tuvieron cerca del Salvador estuvo situada en una tienda y cámara propiedad de Francisco Núñez Muley. AHPrGr; G-137; fol. 1486r/v. Para conocer la labor de la compañía en la ciudad pueden consultarse cofradía, nos hace sospechar que hubo una relación bastante fluida a juzgar por las numerosas actuaciones de Albotodo como testigo de distintas escrituras notariales suscritas por $\mathrm{La}$ Resurrección.

\section{Aunando voluntades: su ascendiente entre los naturales del reino}

Si algo puede afirmarse acerca de La Resurrección sin temor a equivocarse, es el reconocimiento del que gozó entre el colectivo converso. Respeto que atravesó verticalmente toda la sociedad morisca, afianzando su predicamento a medida que avanzaba el tiempo. De hecho, las limosnas al hospital, vía manda testamentaria o vía donación, son tan numerosas como diversa es la procedencia social de los hombres y mujeres que las entregaron, convirtiéndose en su principal medio de financiación. Si el 22 de febrero de 1565, el rico mercader Francisco el Caçar le dejaba en su testamento parte de un molino de aceite ${ }^{45}$, y si don Hernando Muley nombra a La Resurrección su única y legítima heredera ${ }^{46}$, alguien con una capacidad económica más limitada como el cebadero Juan García, le donaba un censo de 1.200 maravedíes, situados sobre ciertos terrenos del término de Gójar ${ }^{47}$. A ellos se unirán personas de condición realmente humilde, como la antigua esclava negra Francisca Hernández. Una mujer que, en 1563, donaba al hospital la parte que a ella le correspondía de la herencia de su difunto marido, Juan de Murcia el Raguaz. Gesto piadoso que secundaría el otro heredero del Raguaz ${ }^{48}$. Los ejemplos podrían multiplicarse mostrando todo un abanico de limosnas: dinero, tierras, árboles frutales, casas, ropa, etc.

Junto a esta unanimidad de apoyos y disparidad de limosnas, cabe referirse a otro de los rasgos que caracteriza a La Resurrección: su notable capacidad de maniobrar en un escenario tan complejo como la sociedad granadina del Quinientos y la tupida red de relaciones que fue capaz de tejer, más allá del propio núcleo urbano de Granada.

los trabajos de Álvarez Rodriguez, "La Casa de la doctrina del Albaicín” y su tesina, Los Jesuitas en Granada (1554-1600).

45 Molino situado a las afueras de la Puerta de Fajalauza. AHPrGr; G-142; fol. 407r.

46 AHPrGr; G-158; fol. 199r/v.

47 AHPrGr; G-131; fols. 562r/563v.

48 AHPrGr; G-133; fols. 411r/412r. 
El 29 de enero de 1563, La Resurrección suscribía, junto a dos mujeres que eran parte interesada en el asunto, una escritura de poder otorgada a favor del señor Rodrigo de Contreras Biedma, veinticuatro de Jaén. En sus nombres, éste debía cobrar:

(...) todos los bienes, oro e plata que quedaron e fincaron por fin e muerte de Diego Hortiz, que falleció en las Yndias del mar océano, en la çibdad de León, en la provinçia de Nicaragua, los quales dichos bienes heredó Hernando Ortiz, hijo legítimo del dicho Diego Ortiz e de María de Torres Pinía ${ }^{49}$.

La prolijidad de datos que incluye la carta nos permite conocer la historia que hay tras su otorgamiento. Hernando, heredero de un morisco que logró embarcar hacia el Nuevo Mundo, había fallecido sin dejar descendencia, instituyendo a su madre, María de Torres, como única heredera. A su vez, ésta otorgó un testamento en el que nombraba como herederos a Pedro de la Peña y a Micaela de León, con la obligación de que ambos dieran una cuarta parte de su herencia a Zacarías de Mendoza y la otra cuarta parte a los pobres del Hospital de La Resurrección. Los implicados, ante la lejanía del patrimonio a repartir, confiaron la gestión de su cobro al citado veinticuatro, Rodrigo de Contreras. Días después, en las nóminas de embarque conservadas en el Archivo de Indias, comprobamos la partida de Biedma a Nicaragua $^{50}$. El montante de la herencia debió ser considerable, dadas las condiciones que el veinticuatro logró pactar ${ }^{51}$.

Pero si el grueso de la financiación de $\mathrm{La}$ Resurrección se debió, con toda seguridad, a las donaciones suscritas ante escribano, no debe pasarse por alto que otro medio nada despreciable de obtener dinero fue la petición directa de limosnas. Una tarea para la que la cofradía contaba con personal y que le permitió darse a conocer en zonas alejadas de la capital. Hasta ahora tenemos conocimiento de la peticiones llevadas a cabo en los pueblos de la periferia y en enclaves más alejados como Or-

49 AHPrGr; G-133, fols. 81v/86r.

50 Archivo General de Indias (AGI), Pasajeros, L.4, E.2613.

51 Se aseguró un tercio del total de la herencia, si conseguía traerla integra a Jaén; en caso contrario, se obligó a pagar a las partes interesadas las dos terceras partes de lo que les hubiera correspondido de la misma. Finalmente, en un gesto no precisamente de confianza, los otorgantes del poder exigieron a Biedma traer desde Nicaragua el testamento y el inventario de bienes de Diego Ortiz. En caso de no hacerlo, los interesados harían ejecución sobre sus bienes por valor de 600 ducados. giva o Las Alpujarras ${ }^{52}$. Actividad para la que tenían, si hemos de creer sus propias palabras, el permiso del provisor del arzobispado.

Los numerosos apoyos que suscitó La Resurrección permiten afirmar que ésta consiguió el reconocimiento de los naturales del reino, sin diferencias de género, procedencia social o, lo más interesante aún, sin diferencias dependientes de su grado de interiorización de la nueva fe. En 1563, un piadoso Luis Fernández, curtidor afincado en San Juan de los Reyes, mandó en limosna, «para ayuda a faser los órganos de la dicha yglesia de San Juan de los Reyes, quatro ducados», y a La Resurrección dos du$\operatorname{cados}^{53}$. Un año antes, Andrés el Valençiano daba medio ducado de oro para la construcción del mismo instrumento musical y medio real a La Resurrección. En 1564, Mencía Hernández, vecina de San Nicolás, legaba a su parroquia cuatro ducados de oro «para ayuda a hacer unas ampolletas de plata», mientras que al hospital morisco entregaba «tres camas de ropa, que cada vna de ellas tenga vn colchón, e dos sávanas, e vna manta freçada de las bastas, e vna almohada, e sus bancos, carcos $e$ tablas». Una limosna esta última que se incrementaría en caso de que su antiguo esclavo negro, al que mandaba una casa y una viña, muriese $\sin$ herederos. Supuesto en el que ambos inmuebles pasarían al hospital ${ }^{54}$. Los ejemplos podrían multiplicarse citando a los moriscos que contaban con sepultura propia dentro de la iglesia, que eran cofrades de las sacramentales de su parroquia o que solicitaron misas «especiales» que permiten entrever su condición de cristianos convencidos. Junto a ellos, representando un porcentaje superior, los moriscos más parcos en gestos piadosos también dedicaron alguna manda a La Resurrección.

Ante esta adhesión, casi sin fisuras, de los naturales del reino a La Resurrección, cabe preguntarse si ésta llegó a tener algún predicamento entre la población cristiano vieja. Y al respecto, resulta sumamente interesante comprobar cómo, de forma puntual, algunos cristianos viejos apoyaron su labor. Ana de San Jerónimo, doncella que dispuso enterrarse en

52 El 18 de junio de 1567, la cofradía da poder a Alonso el Xorayquí y a Gabriel el Malaquí para pedir limosna en Las Alpujarras. Ese mismo día, en los mismos términos, da poder a Miguel Hernández el Calahorri y a Salvador de Mendoza el Guadixi para pedir en Orgiva. AHPrGr; G-158, fols. 693v/694r.

53 AHPrGr; G-131, fols. 1015r/1017v.

54 AHPrGr; G-137; fols. 199r/200v. 
el monasterio de la Vitoria portando su hábito, y que destinó al hospital de Juan de Dios un ducado, tuvo presente «a todos los otros de más ospitales de Granada». Instituciones a las que les remite «otro ducado de oro, el qual se parta entre ellos por yguales partes» ${ }^{55}$. El apoyo cristiano viejo se muestra de forma más nítida entre personas vinculadas al clero secular. Tomás Pérez Serrano, sobrino del canónigo Miguel Pérez, envió mediante manda testamentaria un ducado al hospital de Juan de Dios y dos reales de plata a La Resurrección ${ }^{56}$. Incluso entre el propio clero secular se detectan gestos de apoyo. El bachiller Francisco de Moya, clérigo beneficiado de Almuñécar, solo cobró a los cofrades de La Resurrección veintisiete ducados de los treinta a los que ascendía la deuda que con él tenían contraída: "hazia e hizo graçia e suelta e limosna al dicho ospital del dicho Albayzin» ${ }^{57}$.

\section{Los cofrades de La Resurrección}

Para poner en marcha una empresa como la cofradía y hospital de La Resurrección, era necesario el concurso organizado de personas que apostaran por un tipo muy concreto de asociacionismo, proyectado para perdurar en el tiempo y en el espacio. De entrada, cabe pensar que estamos ante individuos que tenían un considerable conocimiento de los entresijos de la sociedad cristiano vieja y, además, disfrutaban de un grado de comunicación más o menos fluido con las autoridades civiles y eclesiásticas de la ciudad. Premisas que se confirman cuando descubrimos, documento tras documento, sus nombres y sus trayectorias personales.

Partiendo de esta nómina de cofrades de 1563 y considerando la definición dada por Bernard Vincent de «élites moriscas»:

\begin{tabular}{|l|l|}
\hline Alonso Albotodo & Miguel López Arroba \\
Lorenzo Dávila Diguid & Hernán López el Ferí \\
Bernabé Fernández Albeytar & Alonso López el Zaguaque \\
Lázaro Fernández Albeytar & Luis de Mendoza Abenbucar \\
Lorenzo Fernández el Calay & García de Molina \\
Miguel Fernández el Gazi & Diego de Morales Aboamena \\
Lorenzo Fernández Oçaya & Sebastián Navarro Bucar \\
Luis Fernández Zevzem & Andrés Rodríguez el Gamad \\
Cristóbal García & Daniel Sánchez el Zinety \\
Francisco García & Baltasar Suárez el Hipi \\
Miguel Haziz & Sebastián de Talavera el Hagin \\
Juan Hernández Mofadal & Francisco de Torres \\
Damián de Herrera Raxid & Andrés Venegas el Filahe \\
Jerónimo Jiménez el Catin & Alonso Xarquí \\
& Alonso el Xorayqui \\
& \\
\hline
\end{tabular}

Cuadro 1. Relación de cofrades contenida en una escritura de poder de 1563.

55 AHPrGr; G-131; fol.90v.

56 AHPrGr; G-131; fols. 807r/810v.

57 Juan Meldí había comprado al beneficiado Moya una viña de seis marjales, por precio de 30 ducados. Habiendo nombrado como heredera a La Resurrección, tras la muerte de Meldi, la cofradía se hizo cargo de sus deudas. AHPrGr; G-142; fol. 1672r. grupo de moriscos granadinos, nobles de grandes linajes, notables rurales, mercaderes, que pueden ejercer un papel destacado en el seno de la comunidad y en las relaciones de ésta con la sociedad cristiana, en particular con las autoridades. El rasgo común a todos los que se integraron en el mismo, algunas centenas de familias, fue disponer 
de bienes abundantes que les aseguraban al menos vivir con comodidad ${ }^{58}$.

Podemos concluir que, mayoritariamente, los cofrades de La Resurrección conocidos hasta la fecha se integraban en el tercer subgrupo: el de los mercaderes ${ }^{59}$.

\subsection{Esos «hombres ricos del Albaicín»}

Anterior a la definición de Bernard Vincent, Javier Castillo, en su modélico análisis de la sociedad granadina ${ }^{60}$, apuntaba la existencia de distintos grupos entre los moriscos. En la cúspide se situarían los que denomina los hombres de linaje, seguidos de los colaboracionistas y, «a un nivel económico y social equiparable, y frecuentemente formando parte de las mismas familias», «los ricos mercaderes moriscos ${ }^{61}$.

En esta tercera categoría se incluyen casi todos los cofrades de los que, hasta hoy, disponemos de datos. Algunos son tan conocidos como Hernán López el Ferí ${ }^{62}$, otros menos o nada conocidos, pero recuperados gracias a la investigación en el Archivo Histórico de Protocolos de Granada, como es el caso de Alonso Albotodo, Lázaro Fernández Albeytar, Lorenzo Fernández el Calay, Juan Fernández Mofadal, Jerónimo Jiménez el Catín, Lorenzo Hernández Oçaya, Miguel López Arroba o Daniel Sánchez el Zinety. Del resto de cofrades sabemos que algunos ejercieron profesiones liberales, como Baltasar Suárez, escribano del rey, u oficios como Luis Hernández Zevzem ${ }^{63}$, tejedor de terciopelo. De otros desconocemos sus datos biográficos.

Entre los miembros citados destaca Hernán López el Ferí, rico mercader asentado en la colación de San Pedro y San Pablo. Hijo de Juan López el Ferí y nieto de Hernán el Ferí, sus ascendientes disfrutaban de una solvente situación económica, como demuestra el considerable patrimonio inmueble que poseían, integrado por diversas casas principales localizadas en las parroquias de San Pedro y San Pablo, San Blas y el Salvador ${ }^{64}$. Junto a ellas, distintas casas dadas

\footnotetext{
58 Vincent, El río morisco, p. 188.

59 El nombre de los cofrades citados en el cuadro 1 aparece relacionado en una carta de poder concedida por la cofradía de La Resurrección en 1563. AHPrGr; G-131; fol. 558v.

60 Castillo Fernández, "Las estructuras sociales", pp. 179-230.

${ }_{61}$ Castillo Fernández, "Las estructuras sociales”, p. 202.

62 Este interesantísimo personaje ha sido objeto de estudio por parte del profesor Álvarez de Morales, "Lorenzo el Chapíz".

63 En algunas escrituras aparece como Zemzem.

${ }^{64}$ Enrique Soria Mesa nos señala como la posesión de
}

en arrendamiento y múltiples terrenos, como la extensa huerta situada en la ribera del río Darro, colindante con las casas principales que Juan el Ferí compartía con su hermana, Inés Firiha, y el esposo de ésta, Lorenzo el Chapiz ${ }^{65}$. Toda una densa red de propiedades que hacían de Juan el Ferí un «hombre rico», como aseveraban sus convecinos del Albaicín ${ }^{66}$, y como demuestran las distintas donaciones que hizo a lo largo de su vida, unas a familiares, otras a obras pías. Por ejemplo, en su codicilo, datado el 24 de diciembre de 1563, Juan ordenaba pagar a su hijo Hernán los 100 ducados que le había prometido con motivo de su matrimonio. Un dinero que debía ir destinado a la compra de una esclava negra. Días antes, había remitido a la cofradía de La Resurrección, mediante escritura de donación, un censo situado sobre una casa ubicada en Santa Isabel que rentaba 1.800 maravedíes anuales ${ }^{67}$.

Pero de todos los vestigios documentales que nos han quedado de la riqueza y el alto estatus social de los Ferí, uno de los más incontestables es el capital reunido por el hermano del cofrade, Miguel López el Ferí, con motivo de su matrimonio. El 24 de enero de 1563, Miguel, hijo de Juan el Ferí y de María Marça, se desposaba con María Raguida $^{68}$. Entre los diversos bienes que recibió en dote se cuenta una casa situada en el Salvador, con un huerto anexo con naranjos y otros árboles frutales, cocinas y corrales, valorada en 1.000 ducados. Junto a esta casa principal, se le entregaron otras casas y un nutrido grupo de tierras, cerca de la treintena, además de joyas, muebles y ajuar. Sumaba así su dote a un

numerosas casas era algo muy frecuente entre las estirpes de moriscos ricos, aclarándonos que «a las compras y ventas hay que añadir una frenética actividad en cuanto al alquiler de este tipo de bienes, tanto dadas como recibidas en arrendamiento». Soria Mesa, Los últimos moriscos, p. 73.

65 El 22 de diciembre de 1563, Juan López el Ferí y su cuñado el Chapiz, firman una escritura de finiquito. Con ella liquida el Ferí la única propiedad que aún no había partido de la herencia de su padre con su hermana, Inés Firiha. AHPrGr; G-131; fols.1472v/1474r. La casa principal con la que lindaba esta huerta es la actual Casa de Estudios Árabes, el mejor ejemplar de casa morisca que se conserva en Granada.

66 Archivo de la Alhambra (AA), L-188-41. La afirmación queda avalada por múltiples testimonios. Uno de los más elocuentes es la deuda que, por valor de un millón de maravedíes, tenían contraída con él la marquesa de Villanueva del Fresno y sus hermanos y criados. Pérez García y Fernández Chaves, Las élites moriscas. p. 88.

${ }^{67}$ AHPrGr; G-131; fols. 1470v/1471r

68 María es citada como hija de Alonso el Raguí, difunto, y Brianda Halbaça, casada en ese momento en segundas nupcias con Miguel de León el Xarquy. 
total de 1.642 .562 maravedíes y medio. A todas luces, la familia de la novia consideraba que el enlace con la familia Ferí bien merecía tan considerable inversión.

Por su parte, el novio recibió en arras 300 ducados, junto a tierras valoradas en 250 duca$\operatorname{dos}^{69} \mathrm{y}$ :

(...) mill ducados que vos, el dicho mi hijo, aveys recibido y estays entregados dellos, a vuestra voluntad, en trato y cabdal del dicho buestro ofiçio de mercader de sedas, y más vos doy otros doscientos ducados que se entienden por todos mill e dozientos ducados el dicho trato que aveys reçibido ${ }^{70}$.

Como miembro de tan poderosa familia, el patrimonio de Hernán López el Ferí no fue a la zaga del reunido por su hermano. Entre sus posesiones más importantes se hallaba un cortijo situado entre los términos de Colomera y Moclín, llamado de la Alhondiguilla, lindante con tierras de los frailes cartujos que, según datos aportados por Camilo Álvarez, contaba con 250 fanegas de tierra, encerrando en su término cinco casas $^{71}$. Comprendiendo tierras de secano y regadío, el cortijo tenía numerosos animales de labranza, así como personal fijo que atendía a su cuidado, al que se le sumaban arrendatarios y jornaleros eventuales.

No obstante, la actividad que le debió reportar mayores ingresos a Hernán López el Ferí fue la de mercader. Comerciando con productos diversos $^{72}$, sus actividades abarcaron un radio de acción que excedió la frontera del reino granadino $^{73}$. Se trataba casi siempre de productos directamente ligados a la industria textil, principalmente seda. Y precisamente, para la comercialización de este producto llegó a tener una compañía con don Hernando de Fez Muley, personaje al que le unía una sólida amistad, como declaraba el notable granadino en su testamento:

Yten, confieso y declaro que yo he tenido quentas con Hernando López el Ferí, mercader, vezi-

69 AHPrGr; G-131; fols. 157r/163v.

70 AHPrGr; G-131; fols. 164r/165v.

71 Álvarez de Morales, "Notas de Oligarquía morisca granadina".

72 Por ejemplo, 17 de julio de 1567, suscribe una escritura anulando la obligación que tenían dos tintoreros, Lorenzo el Carena y Gaspar Sánchez el Ferreyre, de pagarle 34 ducados por dos quintales de añil que les había vendido. AHPrGr; G-158; fols. $814 \mathrm{r} / 815 \mathrm{r}$.

73 El 15 de abril de 1569, el Ferí daba poder a Luis de Peralta para que cobrase todas las deudas que tenía en Granada y "en la çiudad de Jaen y en otras partes". AHPrGr; G-168; fols. $227 \mathrm{r} / \mathrm{v}$. no desta ciudad, de çiertas sedas que yo del he comprado. Y quentas de la compañía que con él yo he tendio e contratado. E por çierta parte de lo que así me debe, yo le tengo hexecutado e pasaba execuión ante y en vno de los oficios públicos a que yo me refiero. E porque yo tengo mucho amor e voluntad al dicho Fernand López el Ferí, e por buenas obras que yo del he recibido, y por esta clavsulas de testamento, le hago graçia, e suelta, e perdón, de todo lo que paresçiere deverme en la dicha razón ${ }^{74}$.

Pero también mantendrá otra compañía para comercializar distintos tejidos con su hermano Miguel $^{75}$. Telas cuya elaboración controlaba directamente, como puede deducirse de las múltiples obligaciones que suscribe, en la década de los años sesenta, con distintos tejedores que se comprometieron a entregarle determinadas piezas de raso, terciopelo o seda. El procedimiento respondía siempre a un mismo modus operandi, aunque en ocasiones las telas fueron elaboradas en talleres de su propiedad ${ }^{76}$. Toda una planificada y bien controlada red de producción-distribución que contaba con una clientela de elevado poder adquisitivo, como la familia Abenajara ${ }^{77} \mathrm{o}$ don Diego de Castilla, señor de la villa de Gor ${ }^{78}$.

Casado con Beatriz Hermeza, la rebelión alpujarreña no parece que afectara, al menos durante los años que duró el levantamiento, al dinamismo de sus negocios. A pesar de que terminó siendo expulsado del reino ${ }^{79}$, en 1570 todavía permanecía en la ciudad, inmerso en la administración de sus bienes, contando en ese momento con un patrimonio respetable. Punto que se deduce del envío de dinero a su esposa, una de las moriscas que en esa fecha ya había sido expulsada del reino. Situación de desamparo que el Ferí intentó paliar remitiéndole algunos bienes a través de un intermediario, Pedro

74 AHPrGr; G-172.

75 AHPrGr; G-158; fols. 696r/v.

76 En 1563 el Ferí arrienda una casa con cuatro telares, dos para terciopelo llano y otros dos para terciopelo aceituní. Arrienda el inmueble por cuatro años y 20 reales de plata al mes. AHPrGr; G-131; 1355r/1356r.

77 Iñigo López Abenajara y su esposa, María de Molina, junto a su hijo Diego López Abenajara, se comprometían en 1563 a pagar a Hernán López el Ferí 1.680 reales, por la compra de diversas telas. AHPrGr; G-131; fols. 1360v/1362r.

78 El 21 de marzo de 1569, el Ferí da poder a Juan de Vera para que cobre en su nombre al señor de Gor las sedas que le había vendido, así como otras deudas cuyo origen no especifica. El dinero a recibir suma un total de 3.812 reales. AHPrGr; G-172; fols. 138r/v.

79 Así lo anota Álvarez de Morales en los distintos trabajos que tiene sobre la familia Ferí. 
Ruiz, tejedor de damasco, al que da poder el 30 de julio de 1570, para que le entregase en Pastrana:

quarenta coronas en oro, entre senzillas e dobladas cada corona, de a quatroçientos maravedíes de la moneda usual; e vna cadena de oro de çiento y treinta $<$ nueve $>$ eslabones, y más vna saya de tafetán negro guarnesçida con tres ribetones de terciopelo negro, ya forrada en lienço colorado, e vna sobreropa de tafetán asimismo negro, con vn ribete de terciopelo negro, e vn corpiño del mismo tafetán, guarnesçido con vn ribete de terciopelo negro, e vna camisa de mujer de olanda, labrada a la castellana de negro, todo nuevo, los quales dichos bienes y maravedíes de suso declarados el dicho Pedro Ruiz reçibió del dicho Hernán López el Ferí ${ }^{80}$.

A esas alturas del siglo, Hernán López el Ferí ya no disfrutaba de privilegios como el de portar armas, merced que le otorgaría el rey en 1557, tras recibir los informes favorables del conde de Tendilla ${ }^{81}$. Pero a pesar del revés que en su exitosa vida supuso la rebelión Alpujarreña, el último prioste de La Resurrección no parece haber tenido un final trágico como la cofradía. En su exilio ejerció como «procurador de pleitos y asesor fiscal de los príncipes de Éboli y de otros cristianos viejos, además de ocasional recaudador de rentas en sus desplazamientos por Castilla $\rangle^{82}$.

Aunque con un patrimonio más modesto, también Lázaro Fernández Albeytar, vecino de San Pedro y San Pablo, disfrutó de una fortuna considerable. Sirva de testimonio la relación de bienes que aportó al matrimonio, entre los que se contaban: 800 ducados «en oro y trato»; una casa en San Pedro y San Pablo que terminaría vendiendo en 300 ducados; una huerta con casa y árboles en el término de Beiro que vendió por 350 ducados, y tres casas en la colación de San Andrés de cuya venta obtuvo 120 ducados. Su fortuna la logró, principalmente y como ocurrió con otros cofrades mercaderes, gracias al comercio de tejidos, aunque también se aventuró en el complicado mundo de los negocios fiscales. En concreto, junto a su cuñado Diego Fernández el Tavernaxi y a un tal Jerónimo el Albani, se hizo cargo del diezmo del pan de Las Gabias ${ }^{83}$.

80 AHPrGr; G-172; fols. 1062r/1063v.

81 Archivo General de Simancas (AGS), Libro de Cédulas, 156, fol. $176 \mathrm{v}$.

82 Pérez García y Fernández Chaves, Las élites moriscas. p. 125.

83 Tanto la declaración de bienes aportados al matrimonio, como la alusión a los negocios fiscales, están contenidas en el
Sin hijos, a pesar de que en 1564 llevaba casado con Constanza Tavernaxia 22 años, este rico mercader legó su fortuna a su hermano Bernabé Hernández Albeytar, aunque antes había donado parte de su patrimonio a sus sobrinos, Jerónimo Hernández Albeytar y Cecilia Abentacate.

Puntos comunes con Albeitar y el Ferí muestra el también rico mercader Lorenzo Fernández el Calay, aunque sus orígenes fueron más humildes ${ }^{84}$. Vecino del Salvador, casado con Isabel Jabalía ${ }^{85}$, fue hombre solidario con sus congéneres ${ }^{86}$. Propietario de múltiples terrenos que arrendó a distintos moriscos, su posesión más extensa fue el cortijo llamado de la Moraleda, en el que construyó un horno de cal ${ }^{87}$. Dedicado al comercio de diversos tejidos ${ }^{88}$, no fue expulsado durante el levantamiento, aunque tuvo que soportar diversas situaciones abusivas por parte de los soldados de la compañía de Francisco Vela, lo que le llevó a pleitear contra ellos ante Tendilla ${ }^{89}$.

Rompiendo la tónica de los dos anteriores cofrades, mercaderes ricos que nunca se implicaron en las negociaciones de la minoría con la Corona, y entroncando en este punto con el Ferí, sobresale la figura de Juan Fernández Mofadal. Citado por Mármol como uno de los dos acompañantes que llevó don Juan Enríquez a Madrid en su misión de impedir la aplicación de la pragmática de 1566 , sabemos por el cronista que se trataba de un hombre «de buen entendimiento» ${ }^{90}$, que no cejó en su intento de remediar

testamento que otorgó el 25 de noviembre de 1564. AHPrGr, G-137; fols. $1675 \mathrm{v} / 1678$ r.

${ }^{84}$ De hecho, la única donación que su padre, Hernando Hatab, vecino de Santa Isabel, le hizo, constaba tan solo de dos almendros y un granado. AHPrGr; G-142; fols. 1738r/39r.

${ }^{85}$ AHPrGr; G-172; fols. 57r/58v.

86 Son numerosos los testimonios notariales al respecto. Por ejemplo, en 1565, Diego el Çunuçi, uno de los campesinos que trabajaban para él en su cortijo, se obliga a pagarle los 24 ducados que le dejó para «ayuda a pagar çierta condenación de costas e principal en que fui condenado por los señores alcaldes desta corte ante Pedro de la Fuente». AHPrGr; G-142; fols. $1308 \mathrm{r} / 1309 \mathrm{r}$.

87 Curiosamente, en ninguna de las escrituras notariales que he manejado aclaran su localización. No obstante, gracias a Enrique Soria Mesa, sabemos que se hallaba en término de las ciudades de Granada, Alhama y Loja, con una extensión de 1.154,5 fanegas. Soria Mesa, Los últimos moriscos. p. 69.

88 El 4 de noviembre de 1547, Juan Hernández, vecino de Mairena (Ugijar), se obligó a pagarle 17.978 maravedíes que aún le debía por la compra de diversos tejidos. El total de la deuda ascendió a 51.638 maravedíes. AHPrGr; G-68; fols. 290r/v

89 En el pleito les acusa de haberle robado diversos animales. AA, L-78-2-61.

90 Mármol Carvajal, Historia del Rebelión. p. 74. 
lo que era, a todas luces, la sentencia de muerte de cualquier signo identitario morisco, incluso cuando el propio don Juan Enríquez se daba por vencido. Esta resistencia a la política regia en los momentos preliminares a la rebelión arroja sobre él una sombra de duda, alimentada por el propio relato de Mármol. El cronista narra cómo, ante el fracaso de sus gestiones en la Corte y el nulo efecto que tuvieron las súplicas de mediación que elevó al prelado granadino, Mofadal y otros:

(...) desahuciados ya del, comenzaron a resolver algunos jofores o pronósticos que tenían; y disimulando unos, otros más atrevidos, que tenían menos que perder, comenzaron a convocar rebelión ${ }^{91}$.

Quizá, por ser uno de los que más tenían que perder, se implicó en la causa de los rebelados de forma velada, una posición a la que le ayudaba su perfecto conocimiento de los entresijos de la política local y, más concretamente, de la Capitanía del reino. No debe pasarse por alto que, en repetidas ocasiones, Mofadal intervino ante el conde de Tendilla como mediador de algunos ilustres moriscos. Sirva de ejemplo el encargo que le hizo don Enrique Muley, en 1563, para que en su nombre gestionase el cobro de la «lanza muerta» concedida por merced ${ }^{92}$. Otro episodio que demuestra claramente el ascendiente de Mofadal en los círculos de la capitanía es el pleito que mantuvo, estando ya en curso la rebelión morisca, con los soldados alojados en su casa, a los que denunciará por robo. El conflicto se resolvió con sorprendente rapidez a favor del converso. De hecho, el pleito finalizó con la condena de los soldados a los que, significativamente, Mofadal perdonará de inmediato alegando su pobreza y «atento al tiempo santo en que estamos» ${ }^{93}$.

A este esbozo de su trayectoria personal podrían sumarse algunos datos aislados. Entre ellos, cabe indicar que era vecino de San Pedro y San Pablo, que estaba casado y que tenía hijos. Concretamente, en el pleito aludido menciona a una hija, casada con un tal Iñigo de Mendoza, que vivía con él. El otro apunte biográfico lo conocemos gracias a un testamento, el de su hermana Mayor Mofadala. Vecina de la Zubia,

\footnotetext{
91 Mármol Carvajal, Historia del Rebelión. p. 75.

92 AHPrGr; G-131; fols. 654v/655v. Las intervenciones de Mofadal a favor de don Enrique Muley fueron múltiples.

93 Los soldados habían sacado de la casa de Mofadal importantes cantidades de trigo, cebada, aceite, ropas y dinero. AA, L-78-1-26.
}

estuvo casada con Martín Çayad y era madre de dos hijas: Isabel Çayda, vecina de Ugijar, casada con García el Bagigí, y Beatriz Çayda, soltera. Por las distintas mandas y aclaraciones testamentarias, se deduce que Mayor estuvo siempre bajo la protección de su hermano, quien administró su hacienda.

Hasta aquí, todo lo apuntado sobre Mofadal nos lo presenta como un individuo comprometido con sus hermanos de nación. Sin embargo, existen datos biográficos que rompen esta visión y nos muestran la compleja $-\mathrm{y}$ a veces contradictoria- situación vivida por ese «hombre de buen entendimiento». Y es que Mofadal, como repartidor de la farda de su parroquia, no tuvo una actitud ni tan valiente ni tan desinteresada hacia los suyos. Por el contrario, sus vecinos lo rechazaron como repartidor, alegando que actuaba «en perjuizio de muchos vezinos de la dicha parroquia», no siendo ecuánime en el reparto del servicio. Para alejarlo del cargo, argumentaron que su nombramiento iba «contra derecho», ya que Mofadal era cristiano viejo ${ }^{94}$. Un privilegio concedido por la Corona, no sabemos en función de qué méritos, que Mofadal debió usar a conveniencia, pero que no le sirvió de nada una vez desencadenado el conflicto. Así, el 19 de julio de 1570, fue capturado por las tropas cristianas en Güejar Sierra, junto a otros rebelados ${ }^{95}$.

Idéntico destino esperaba a otro de los cofrades de La Resurrección, Lorenzo Hernández Oçaya. Repartidor de la farda, rico mercader del Salvador centrado en el negocio de la seda y poseedor, como los anteriores cofrades, de un patrimonio inmueble considerable, compuesto por terrenos dispersos por el área metropolitana ${ }^{96}$ y tiendas en la Alcaicería ${ }^{97}$. Casado con Elvira Hernández, tuvo un único hijo, Damián Hernández Oçaya, geliz de la seda. A él iría destinada una donación que, otorgada por razón de sus esponsales con Mayor de Mendoza Yzbola, comprendía diversas hazas, un viñedo, una tienda y una casa en el Salvador ${ }^{98}$.

94 AA, L-159-40-216.

95 AGS, CC, leg. 2.154. fol. 292. Agradezco a Javier Castillo el que me haya facilitado este dato.

96 Oçaya arrienda estos terrenos a otros moriscos, como el haza de 7 marjales que entrega al herrador Sebastián Azaraque, por tiempo de 4 años y 48 reales anuales de renta. AHPrGr; G-68; fols. 738r/v.

97 El 28 de agosto de 1554 arrienda a Alvaro el Cayli una tienda situada en el Salvador. El tiempo de arrendamiento es también de 4 años, pagando mensualmente 4 reales y medio. AHPrGr; G-83; fols. 359r/v.

98 AHPrGr; G-159; fols. 353r/354v. 
Pero este privilegiado estatus social no libró a Oçaya de pasar un tiempo en prisión. Por el contrario, su condición de «hombre rico» le condujo a ella. Ningún dato conocido hasta la fecha nos lo revela como traidor, criptomusulmán o defraudador fiscal. Su detención y encarcelamiento parece enmarcarse en las detenciones preventivas llevadas a cabo contra los acaudalados del Albaicín. Una medida adoptada como «corta fuegos» ante los rumores de una posible sublevación. Como indicó Bernard Vincent, cabe preguntarse si este episodio no obedeció a una operación «deliberada, destinada a desembarazarse de los moriscos de Granada capaces de arrastrar al Albaicín a la rebelión ${ }^{99}$. Fuese cual fuese la causa de su encarcelamiento, su puesta en libertad fue recibida por sus convecinos con alivio. De hecho, por intermediación de los repartidores del Salvador, no tardaron en solicitar al conde su inmediata restitución en el cargo de seise. La razón esgrimida no será otra que el hecho de ser Oçaya «repartidor viejo»y, por ende, "entiende mejor» el negocio que la persona que lo había sustituido en el oficio ${ }^{100}$.

Compartiendo la experiencia de la cárcel, hallamos al que fuera mayordomo de la cofradía de La Resurrección, Miguel López Arroba. Hijo de Juan Arroba y de Isabel Delgadillo Farduça, tuvo cuatro hermanos: Alonso, Lorenzo, Ambrosio y Sebastián ${ }^{101}$. Su madre le donará, el 30 de agosto de 1568, distintas propiedades, entre las que cabe citar la cuarta parte de una casa principal en la colación de San Miguel, parroquia de la que era vecino, así como diversos terrenos y la cuarta parte de una casa-tienda, «que son en donde vos el dicho Miguel López Arroba, mi hijo, al presente teneys vuestro trato ${ }^{102}$. Desconozco si, al margen de sus actividades como mercader, Miguel fue socio de su hermano Alonso López Arroba, cerero de oficio y hombre realmente emprendedor, entre cuyas inversiones destaca la compañía que formó con otros moriscos para explotar una aduana de azúcar situada en Patabra ${ }^{103}$.

\footnotetext{
99 Vincent, El Rio morisco. p. 96.

100 AA, L-154-40-16.

101 En 1565 Sebastián es citado como difunto.

102 AHPrGr, G-159, fols. 904v/907v.
}

103 AHPrGr; G-116; fols. 27v/29r. Sobre Alonso López Arroba, la fuente notarial arroja más información de la que hasta la fecha he podido encontrar sobre Miguel. Entre otros documentos interesantes sobre Alonso, aparte de sus inversiones en el negocio azucarero, tenemos la dote de su segundo matrimonio, fechada el 29 de mayo de 1563. Dote que monta un total de 331.812 maravedíes, aportados por su esposa Inés Raxida.
Pero su exitosa actividad comercial cesó bruscamente tras el levantamiento. El 26 de marzo de 1569, desde la cárcel de la Alhambra, remitía a Tendilla una desesperada petición solicitando que se le tomase declaración ${ }^{104}$. Requerimiento al que, según parece, el conde hizo oídos sordos, motivo por el cual, meses después y de forma conjunta con Jerónimo de Palacios, Lorenzo de Berrio, Lorenzo Hernández el Chapiz y Pedro López Çaybona, pidió su traslado a otras dependencias de la prisión. En el documento el grupo se presenta como gente «llana, pacífica», que habiendo cumplido con sus fianzas seguían aún «presos, sin culpa, nueve meses» ${ }^{105}$. Esta situación no era nueva para Arroba. En 1565, como fiador de un morisco huido allende, un tal Rodrigo el Fadil, ya estuvo encarcelado en la Alhambra y condenado a pagar 133 duca$\operatorname{dos}^{106}$. Por el pleito incompleto que se conserva en torno a este suceso, sabemos que Miguel López Arroba, tras conocer el fallo, entregó de inmediato 70 ducados en dinero efectivo y en prendas de oro y plata. El suceso nos proyecta la imagen de un converso solvente, pero, a la par, siembra la duda sobre el grado de vinculación entre ambos. ¿Pagó caro Miguel su gesto generoso hacia uno de los suyos, sin otras lecturas? o, por el contrario ¿conocía las intenciones de huida del Fadil, simpatizaba con su proyecto y por ello no le importó exponerse a las posibles represalias que le aplicaría la Corona?

Una trayectoria exitosa, sin los altibajos vividos por Mofadal, Oçaya o Arroba, fue la que tuvo Jerónimo Jiménez el Catín. Un acaudalado mercader, cuya trayectoria ilustra a la perfección las estrategias matrimoniales desplegadas por estas élites económicas. Política de enlaces brillantemente analizada por Enrique Soria Mesa, que dio lugar a la consolidación de bloques compactos de individuos relacionados por la parentela, conformando una «endogamia de nación» ${ }^{107}$.

\footnotetext{
104 AA, L-78-2-43.

105 AA, L-78-2-47.

106 AA, L-80-10.
}

107 Esta estrategia apuntada por Soria Mesa es secundada en los trabajos de otros historiadores. Concretamente, Javier Castillo describió como las categorías sociales de segundo plano «casaban con linajes eminentes de la misma localidad $u$ otra localidad, pero preferentemente de estirpe morisca». Las relaciones familiares entre esta clase dirigente de tipo medio abarcan casi todo el reino, entre otras cosas por la importancia que ya cobra entre ellos el parentesco matrilineal, inexistente en la cultura árabe, pero muy importante en la cristiana. Castillo Fernández, "Las estructuras sociales". p. 203. El propio Enrique Soria Mesa ya apuntaba en sus primeros trabajos el 
Vecino de San Miguel, Jerónimo el Catín casó con Elvira Agima, de cuyo matrimonio tuvo un hijo: Juan Jiménez el Catin, también mercader y vecino de San Miguel. El matrimonio de éste con doña María Venegas, hija de Alonso Venegas y doña Brianda Abenhinia, sellaba la alianza de su familia con una de las más respetadas del reino: los Granada Venegas de Monachil, rama menor del gran tronco nobiliario de los señores de Campotejar, que estuvo emparentada con casi todas las familias moriscas del reino pertenecientes a la élite económica ${ }^{108}$.

La dote aportada al matrimonio por doña María Venegas fue tasada por Hernando el Jabaliz y Diego Hermez, mercaderes, en 759 ducados. Por su parte, Juan Jiménez el Catín aportó en arras 200 ducados, más una serie de bienes donados a la novia cuyo valor ascendía a 370 ducados. En total, dote y arras sumaron 1.329 ducados. De este matrimonio nacerán varios hijos entre los que cabe destacar a Alonso Jiménez Venegas, quien casó con Beatriz López Palomino. Un hijo de esta pareja, Jacinto Jiménez Venegas, terminó litigando para que se le reconociese su condición de hidalgo. Irónico, pero no sorprendente final, para una familia que tuvo entre sus ascendientes a un cofrade de La Resurrección que en el momento de la expulsión definitiva alegó su condición cristiano vieja. De hecho, remontó su origen «hasta supuestos conquistadores del reino de Granada, venidos a estas tierras de la mano de los gloriosos Reyes Católicos», desde Murcia ${ }^{109}$.

Una política matrimonial semejante, aunque sin establecer alianzas con la nobleza, es la desplegada por otro de los grandes mercaderes granadinos: Daniel Sánchez el Zinety. Vecino del Salvador, hijo de Lope Sánchez el Zinety, se dedicó al comercio de la seda y otros bienes, entre lo que cabría destacar los animales de labranza $^{110}$. También sumaba entre su patrimonio

despliegue por parte de esta élite económica de tres tipos de estrategias matrimoniales: 1) en una primera fase se trataría de enlazar con familias situadas en el mismo estatus social. 2) En una segunda etapa, se buscaría emparentar con la nobleza morisca, fase a la que se llega a mediados de la centuria del Quinientos. 3) Finalmente, una vez eludida la expulsión, se emparentaría con clases medias cristiano viejas. Soria Mesa, "La asimilación de la élite morisca" p. 652.

108 Soria Mesa, "Entre reyes moros y oscuros labradores cristianos", pp. 159-182.

109 Soria Mesa, "Entre reyes moros y oscuros labradores cristianos", p. 176.

110 Sirva de ejemplo la escritura por la que Lorenzo el Çabaní, hornero, vecino de San Luis, se obliga a pagarle 16 inmueble un cortijo, en su caso ubicado en Alhama y conocido como el «Turro» ${ }^{111}$. Casado con María Nayara, tuvo dos hijos: Sebastián Suárez el Zinety y Elena Sánchez Zinety, a quien casó con Lorenzo López de Berrio, dándole en dote 2.000 ducados $^{112}$. Alianza matrimonial que supuso la unión con una de las familias de mercaderes más importantes del reino ${ }^{113}$.

A la gestión del patrimonio y a su participación en la cofradía, el Zinety sumó el desempeño puntual de algunas labores de representatividad de los de su nación. Así, en 1560, llevó junto al Chapiz, y en nombre de los moriscos del Reino, unos presentes de boda a Felipe II. Por supuesto, la intención no era otra que ganarse el favor del rey Prudente. Acción a la que el soberano respondería con cortesía:

Y así la voluntad con que dezis que nos lo embiaís, que es conforme a la que en mi ay para os favorecer y hazer merced y mandar mirar vuestras cosas, como más particularmente lo hauemos dicho a los dichos Lorenço Hernández y Daniel Sánchez ${ }^{114}$.

\subsection{Los cofrades ¿ejemplo de éxito o de fracaso de la política evangelizadora?}

Hasta donde conocemos, los cofrades de La Resurrección aparecen hermanados entre sí por un modus vivendi similar. Solventes económicamente, practicando una política matrimonial endogámica destinada a consolidar su estatus, con un dominio destacable de la lengua de los vencedores $^{115}$ y un controvertido ascendente entre los suyos, parece que hubo por su parte un esfuerzo real de acoplamiento a la sociedad vencedora, incluso en el tema que más espinoso podría resultarles: el religioso.

De entrada, su perfil piadoso se podría caracterizar por guardar una significativa equidistancia entre el mostrado por la mayoría de sus hermanos

ducados de oro por un buey de arada, de color bermejo. AHPrGr; G-68; s.f. La carta lleva fecha del 23 de mayo de 1555.

111 AHPrGr; G-147; foliación ilegible.

112 Dato contenido en el testamento que otorgó el 13 de septiembre de 1563. AHPrGr; G-131; fols. 1031r/1034r.

113 La entrega de tan importante patrimonio a su hija, vendrá compensada en su testamento por la mejora de tercio hecha a su único descendiente varón. Una disposición que le supondrá a éste, Sebastián, recibir en herencia un molino de aceite situado fuera de la puerta de Fajalauza, con tierras y árboles anejos, así como el cortijo del Turro.

114 AGS; Libro de Cédulas 256, fol. 186v.

115 Sin necesitar ninguno de los cofrades la asistencia de un traductor, el trazado de sus firmas revela, además, un dominio claro de la escritura castellana. 
de nación, y el exhibido por los cristianos viejos ubicados en su mismo estatus económico. De los primeros, los cofrades de La Resurrección se distinguieron por haber asumido un abanico más amplio de rituales católicos, especialmente los ligados a la muerte. De los segundos, se distanciaron por su imposibilidad de asimilar algunas de las pautas de comportamiento más enraizadas en la tradición cristiana. Así ocurrió con la práctica de invertir a largo plazo en la salvación a través de las fundaciones piadosas destinadas a financiar la celebración de misas ${ }^{116}$.

No es de extrañar por tanto que, en su nueva condición de cristianos, contradiciendo las preferencias del resto de moriscos ${ }^{117}$, todos los cofrades opten por sepulturas en el interior de sus respectivas parroquias, contando incluso con enterramientos familiares ${ }^{118}$. Sirva de ejemplo Lázaro Fernández Albeytar, enterrado en la sepultura de su padre, Alonso de Baza Albeytar, situada en el interior de San Pedro y San Pablo ${ }^{119}$. Otros cofrades incluso van más allá al ubicar sus sepulturas en lugares cargados de simbología, mostrando así la total interiorización de los rituales funerarios más emblemáticos del catolicismo. Es el caso de Lorenzo Hernández Oçaya al disponer «quel dicho enterramiento de mi cuerpo, a de ser en la sepultura que yo tengo junto a la pila del baptismo de la dicha yglesia ${ }^{120}$. A la par, existe también entre ellos un deseo de individualizar la sepultura, de que ésta

116 Por el contrario, otras fundaciones pías de carácter caritativo no eran extrañas al islam. Conviene recordar la gran importancia que tuvo el sistema de donación islámica conocido como waqf. Se trataba de ceder a perpetuidad el uso o usufructo de una propiedad, financiando con ello una institución de utilidad pública, en múltiples ocasiones destinada a pobres o discapacitados. En al-Andalus, como revelan las fuentes árabes, era habitual que sus habitantes destinaran parte de sus fortunas a pobres y enfermos. En este sentido, la fundación de un hospital como el de La Resurrección entroncaría con esa tradición. Sobre el tema del waqf pueden consultarse, entre otros, los trabajos de Carballeira Debasa, "Aproximación a las donaciones piadosas en el islam medieval"; Cuenca Boy, "Para una comparación histórico-jurídica de las piae causae del derecho romano justinianeo con el waqf del derecho islámico"; Feijoo, "Cristiandad e islam: actos piadosos y caritativos entre dos mundos" o el estudio de García Sanjuan, Hasta que Dios herede la tierra.

117 En la tradición musulmana los cementerios siempre debían estar extramuros de la ciudad, fuera del contacto con los vivos.

118 Una práctica nada extraña en la tradición islámico-sufí, donde se han constatado numerosos entierros dentro de las zāwiyas.

119 AHPrGr; G-137; fol. 1676r.

120 AHPrGr; G-172; fol. 55r. se convierta en recordatorio permanente de su persona, sentimiento que lleva a Daniel Sánchez el Zinety a pedir que se coloque en ella «vna piedra con su letrero a costa de mis bienes» ${ }^{121}$.

En la misma línea, la demanda de un numeroso cortejo funerario, la petición de misas a familiares, la pertenencia a la hermandad sacramental de la parroquia y, como no, el hecho de formar parte de una cofradía fundada y organizada según el más rancio modelo cristiano viejo, nos desvela, en principio, a unos hombres «en paz con Dios».

Recapitulando todo lo dicho en las páginas precedentes, bien podríamos considerar a los cofrades de La Resurrección como una minoría privilegiada dentro de la minoría, como un grupo humano que, a pesar de vivir con el identificativo de «moriscos», supo medrar en la nueva sociedad cristiana. Hasta lo que conocemos de sus biografías, no fue para ellos un escollo insalvable el nuevo credo religioso, la nueva dinámica económica o la nueva organización institucional - de la que consiguieron ser una pieza más de su engranaje-, ni tan siquiera la lengua impuesta. Sin embargo, sería engañoso pensar que no existió tensión alguna en sus vidas, que estas transcurrieron ajenas a la difícil tesitura a la que se vio sometida la nación a la que pertenecían. Una reflexión que puede hacerse extensible al Hospital, y que nos lleva de nuevo al punto de partida de este trabajo: ¿Nació La Resurrección para la conspiración o, por el contrario, se vio abocada a tomar partido una vez estallada la Rebelión de 1568? ¿Podemos considerarla ejemplo de éxito o, por el contrario, de fracaso de la política evangelizadora iniciada por Talavera?

Talavera, escribe Isabella Iannuzzi, es hijo de una tradición que creía en la transformación de las comunidades mediante una estrecha colaboración entre el poder político y el religioso. Para el jerónimo, era factible organizar una sociedad en la que las diversidades quedasen asimiladas en nombre de un camino «común, indicado por la monarquía, y de valores comunes, los de la fe cristiana». Para ello, entre otras medidas, «dio acogida a una espiritualidad más popular mediante la creación de cofradías y hermandades y mediante

121 AHPrGr: G-131; fol.1031r. Sobre el uso de lápidas con inscripciones - en principio no bien vistas en el islam-, resulta muy revelador el trabajo de Ana Echevarría sobre los enterramientos y ritos funerarios observados por los musulmanes y mudéjares toledanos. Estudio que revela la existencia de una cofradía adscrita a la mezquita toledana. Echevarría Arsuaga, "Enterramientos y ritos funerarios islámicos". 
un lenguaje litúrgico que el pueblo pudiera asumir» ${ }^{122}$. Una convicción que le llevó a recomendar a los moriscos del Albaicín que tuviesen «cofradías como las tienen los cristianos para los ayudar de ellas en muerte y en vida» ${ }^{123}$. Una propuesta que hizo en el escenario de una política evangelizadora muy activa y fundamentada en el ejemplo, en la que se priorizó la atención a pobres y enfermos. De hecho, testimonios coetáneos coinciden en describir la casa del Arzobispo como un lugar que era a la vez «convento, hospicio y hospital... Albergabanse alli cuantos pobres cabían materialmente en el local, llegando algunas veces a doscientos cincuenta $\rangle^{124}$. Esta incansable labor fructificó en la creación de hospitales como el de San Lázaro, destinado a los moriscos afectados por enfermedades englobadas bajo la denominación de lepra, cuya primera ubicación fue, precisamente, la plaza de Bibal Bonut.

«Mi voto y el de la reyna - proclamaba Fernando el Católico- es que estos moros se baptizen, y sin ellos no fuessen cristianos, seránlo sus hijos, o sus nietos» ${ }^{125}$. La creación de La Resurrección parece darle la razón al rey. De entrada, por la propia naturaleza de la fundación: una cofradía de naturales, es decir, una asociación de laicos agrupados en función de su origen común (conversos del islam), en la que las relaciones del grupo con la sociedad cristiano vieja, con la jerarquía eclesiástica y entre ellos mismos, fueron originadas, definidas y articuladas a partir de las ideas religiosas predominantes en la España de la Contrarreforma. Lo que presupone un conocimiento directo, más o menos profundo, de las mismas o, cuanto menos, un contacto fluido con quienes difundían la nueva sensibilidad tridentina. Aunque, bien es verdad, que la actividad piadosa de esta cofradía morisca se canalizó a través de un hospital, institución que también gozaba en el mundo islámico de una larga tradición, «sin olvidar que la constitución de cofradías asistenciales que cubrían a la vez funciones religiosas, caritativas, funerarias y mutualistas, es bien conocida tanto en el islam como en la Europa cristiana, con especial apogeo a partir

122 Iannuzzi, "La labor catequética de fray Hernando de Talavera", p. 58.

123 Esta fue una de las recomendaciones que dio Talavera a los vecinos del Albaicín. Texto reproducido en distintos trabajos, entre ellos el de Framiñán de Miguel, "Manuales para el adoctrinamiento de neoconversos", pp. 25-37.

124 Fernández Fidel, Fray Hernando de Talavera. p. 229.

125 Cita incluida por Pérez en su libro Isabel la Católica, p. 89 . del siglo XIII $\rangle^{126}$. Concretamente, Castilla contó con importantes cofradías mudéjares, algunas tan interesantes como la fundada en la aljama de Toledo, o cofradías mixtas como la de San Eloy y San Antón, en Segovia ${ }^{127}$. Tradición a la que, parece, no fue ajeno el reino de Granada, donde proliferaron tariqas y cofradías ${ }^{128}$.

Pero al margen de lo que a todas luces parece una acertada síntesis de ambas tradiciones, cristiana y musulmana, no podemos pasar por alto la novedad que supone crear un espacio de cohesión, como al fin y al cabo fue La Resurrección, gestionado por y para moriscos, en sintonía con las aspiraciones de las autoridades cristiano viejas. Hasta su erección, teniendo como telón de fondo la más que cuestionable operatividad de la figura del procurador general de los moriscos, las estrategias de supervivencia de la minoría y, en el mejor de los casos de integración de algunos de sus miembros, pasaron por tres vías fundamentales y complementarias. Vías que transitaban desde las iniciativas particulares y familiares hasta las colectivas. Entre las primeras, sirva de ejemplo las mercedes solicitadas argumentando la conversión voluntaria al cristianismo. Entre las segundas, la política matrimonial a través de la que se consolidaban bloques compactos de individuos relacionados por la parentela. Finalmente, las apuestas colectivas en las que todos, como integrantes de una misma nación, pactaban compromisos puntuales con la Corona a manera de balones de oxígeno, previo pago de sustanciosas cantidades de dinero en forma de «servicios», y previa intermediación de las élites.

Con la creación de La Resurrección, cabe preguntarse si parte de los miembros más destacados de la sociedad granadina no estaban intentando sumar una estrategia más de supervivencia, si no estaban articulando otro mecanismo de cohesión interna ajeno al pacto fiscal. Y esta vez apostando por una vía normalizada, en sintonía con las ideas contrareformistas coetáneas a su fundación, pero también con raíces en la predicación y ejemplo

126 Mayor, Echevarría, "Hermanos y cofrades en la Aljama de Toledo", p. 174.

127 Una realidad sumamente interesante la de estas cofradías mixtas en las que cada cofrade, musulmán o cristiano, tienen idénticos derechos y obligaciones, pero en la que cada uno jura y cumple según su ley, expresando así una «convivencia cofrade por encima de las adscripciones religiosas bajomedievales». Gómez García, "Los mudéjares menestrales segovianos", p. 39.

128 Rodríguez Mañas, "Encore sur la controverse entre soufis et juristes au moyen âge". 
de Talavera. Un arzobispo que había pedido en su testamento a los cristianos guardar «el vínculo de la caridad» ${ }^{129}$. Y esta apuesta por mantener el vínculo de la caridad a través de la acción de una cofradía parece que perduró entre los moriscos granadinos después de su expulsión. Un ejemplo lo tenemos en la cofradía fundada en Villanueva de la Serena (Badajoz), a finales del siglo XVI, bajo el nombre de San José. Hermandad que, como apunta Esteban Mira, «al parecer, fue instituida por un morisco de origen granadino, Miguel Hernández Murcia, aglutinando en torno a ella a los conversos de la localidad que, al parecer, eran buenos cristianos» ${ }^{130}$.

\section{Fuentes de Archivos}

Archivo de la Alhambra, L-78-1-26; L-78-2-43; L-782-47; L-78-2-61; L-80-10; L-156-40-16; L-159-40216; L-188-41.

Archivo General de Indias, Pasajeros, L.4, E.2613.

Archivo General de Simancas, Libro de Cédulas, 156; Libro de Cédulas ,256; Cámara de Castilla, leg.2.154.

Archivo Histórico Diocesano de Granada

- Contaduría, legajo 330F; legajo 333F/2 (1)

Archivo Histórico de Protocolos de Granada

- Protocolos: G-68; G-83; G-106; G-109; G-111; G-112; G-115; G-116; G-125; G-131; G-137; G-142; G-147; G-158; G-159; G-168; G-172; G-242.

\section{Bibliografía}

Álvarez de Morales, Camilo, "Lorenzo el Chapiz y el 'Negocio General' de 1559”, Qurtuba, 1 (1996), pp. 11-38.

Álvarez de Morales, Camilo, "Notas de la oligarquía morisca granadina. La familia Ferí", Sharq al-Andalus, Estudios mudéjares y moriscos, 14-15 (1997-1998), pp. 155-176.

Álvarez de Morales, Camilo y Girón Irueste, Fernando, "Maristanes y Hospitales", en María Jesús Viguera Molins (coord.), Ibn Jaldun: el Mediterráneo en el siglo XIV: auge y declive de los imperios. Exposición en el Real Alcázar de Sevilla, mayo-septiembre 2006, Granada, Fundación Legado Andalusí - Fundación José Manuel Lara, 2006, pp. 276-285.

Álvarez Rodríguez, Josefa Rosaura, "La Casa de la doctrina del Albaicín. Labor apostólica de la Compañía de Jesús con los moriscos", Cuadernos de la Alhambra, 19-20 (1983-1984), pp. 233-246.

129 Ladero Quesada, "Fray Hernando de Talavera en 1492", p. 257.

130 Mira Caballos, "Cofradías étnicas en la España Moderna", p. 66.
Álvarez Rodríguez, Josefa Rosaura, Los jesuitas en Granada (1544-1600). La Casa de la Compañía, Granada, Memoria de licenciatura leída en la Universidad de Granada, 1985.

Antolínez de Burgos, Justino, Historia eclesiástica de Granada, Manuel Sotomayor (estudio), Granada, Universidad de Granada, 1986.

Barrios Rozúa, José Manuel, Guía de la Granada desaparecida, Granada, Comares, 1999.

Bermúdez de Pedraza, Francisco, Historia eclesiástica de Granada. Antigüedad y excelencia de Granada, Granada, Universidad de Granada, 1989, colección Archivium 12.

Cambil Hernández, María de la Encarnación, $L a$ Arquitectura asistencial en Granada: siglos (XVI$X X I)$, Granada, Tesis doctoral leída en la Universidad de Granada, 2007, [en línea], disponible en: $<$ http://hdl.handle.net/10481/1469>, [consultado el 15/04/2020].

Carballeira Debasa, Ana María, "Aproximación a las donaciones piadosas en el islam medieval: el caso de al-Andalus", en Alfonso García Leal (coord.), Las donaciones piadosas en el mundo medieval, Oviedo, Universidad de Oviedo, pp. 385-406.

Caro Baroja, Julio, Los moriscos del Reino de Granada, Madrid, Istmo, 2000.

Castillo Fernández, Javier, "Las estructuras sociales", en Manuel Barrios Aguilera, Rafael Gerardo Peinado Santaella (coord.), Historia del Reino de Granada. La época morisca y la repoblación (1502-1630), Granada, Universidad de Granada, 2000, 2 vols., pp. 179-230.

Cuenca Boy, Francisco, "Para una comparación históricojurídica de las piae causae del derecho romano justinianeo con el waqf del derecho islámico", Anuario da Facultate de dereito da Universidade da Coruña, 6 (2002), pp. 273-312.

Echevarría Arsuaga, Ana, "Enterramientos y ritos funerarios islámicos: de lo andalusí a lo mudéjar a través del caso toledano", Studia Histórica. Historia Medieval, 38 (2010), pp. 81-112.

Feijoó, Manel, "Cristiandad e islam: actos piadosos y caritativos entre dos mundos", en Alfonso García Leal (coord.), Las donaciones piadosas en el mundo medieval, Oviedo, Universidad de Oviedo, 2012, pp. 407-423.

Fernández, Fidel, Fray Hernando de Talavera: confesor de los Reyes Católicos y primer arzobispo de Granada, [en línea], disponible en: <http://www. cervantesvirtual.com/nd/ark:/59851/bmc059k5>, [consultado el 23/05/2020].

Fernández, Fidel, Fray Hernando de Talavera, confesor de los Reyes Católicos y primer arzobispo de Granada, Madrid, Biblioteca Nueva, 1942. 
Framiñán de Miguel, María Jesús, "Manuales para el adoctrinamiento de neoconversos en el siglo XVI", Criticón, 93 (2005) pp. 25-37.

Gallego y Burín, Antonio, Granada. Guía Artística e Histórica de la ciudad, Madrid, Fundación Rodríguez Acosta, 1961.

García Granados, Juan Antonio, Girón Irueste, Fernando y Salvatierra Cuenca, Vicente, El Maristán de Granada: un hospital islámico, Granada, Asociación Española de Neuropsiquiatría y Asociación Mundial de Psiquiatría, 1989.

García Pedraza, Amalia, Actitudes ante la muerte en la Granada del siglo XVI. Los moriscos que quisieron salvarse, Granada, Universidad de Granada, 2 vols.

García Sanjuan, Alejandro, Hasta que Dios herede la tierra: los bienes habices en al-Andalus (siglos $X-X V$ ), Huelva, Universidad de Huelva, 2002.

Garrido Aranda, Antonio, Organización de la Iglesia en el Reino de Granada y su proyección en Indias, siglo XVI, Sevilla, Escuela de Estudios HispanoAmericanos, 1979.

Gómez García, Luz, "Los mudéjares menestrales segovianos", Sharq al-Andalus, 14-15 (1997-1998), pp. $35-45$.

Gómez-Moreno González, Manuel, Guía de Granada, Granada, Universidad de Granada, 1982.

Henríquez de Jorquera, Francisco, Anales de Granada: descripción del reino y ciudad de Granada, crónica de la reconquista (1482-1492), sucesos de los años 1588 a 1646, Granada, Universidad de Granada, 1987, 2 vols., colección Archivium, 1.

Hurtado de Mendoza, Diego, Guerra de Granada, Bernardo Blanco González (ed.), Madrid, Castalia, 1970.

Iannuzzi, Isabella, "La labor catequética de fray Hernando de Talavera hacia los moriscos", Áreas, 30 (2011), pp. 53-62.

Jesús, Fray Pedro de, Templo nuevo de los Agustinos Descalzos de Granada, y sumptuosas fiestas que se celebraron á su dedicación, con el título de $N$. Señora de Loreto, desde el día 23 de octubre, hasta el día primero de noviembre de este año de 1694, con vna breve descripción del sitio, y antigüedad de la nobilissima coronada ciudad de Granada, Granada, Imprenta de Francisco Gómez Garrido, 1695.

Ladero Quesada, Miguel Ángel, "Fray Hernando de Talavera en 1492: de la Corte a la misión", Chrónica Nova, 34 (2008), pp. 249-275.

López Guzmán, Rafael, Tradición y clasicismo en la Granada del siglo XVI. Arquitectura civil y urbanismo, Granada, Diputación Provincial de Granada, 1987.
Mármol Carvajal, Luis del, Historia del Rebelión y castigo de los moriscos del reino de Granada, Javier Castillo Fernández (ed.), Granada, Granada \& Tres Fronteras Ediciones \& Diputación de Granada, 2015.

Mayor, Rafael y Echevarría Arsuaga, Ana, "Hermanos y cofrades en la aljama de Toledo a principios del siglo XV", Anaquel de Estudios Árabes, 26 (2015), pp. 163-185.

Mira Caballos, Esteban, "Cofradías étnicas en la España Moderna: una aproximación al estado de la cuestión”, Hispania Sacra, 66 (2014), pp. 57-88.

Pérez, Joseph, Isabel la Católica ¿un modelo de cristiandad?, Granada, Universidad de Granada, 2007.

Pérez García, Rafael M. y Fernández Chaves, Manuel F., Las élites moriscas entre Granada y el Reino de Sevilla. Rebelión, castigo y supervivencias, Sevilla, Universidad de Sevilla, 2015.

Pérez de Hita, Ginés, La Guerra de los Moriscos (Segunda parte de las Guerras Civiles de Granada), Joaquín Gil San Juan (ed.), Granada, Universidad de Granada, 1998.

Rodríguez Mañas, Francisco, "Encore sur la controverse entre soufis et juristes au moyen âge: critiques des mécanismes de financement des confréries sufíes", Arabica, 43, 3 (1996), pp. 406-421.

Santibáñez, Juan de, Historia de la Provincia de Andalucía de la Compañia de Jesús, Reproducción digital del original conservado en la Biblioteca de la Universidad de Granada.

Soria Mesa, Enrique, "La asimilación de la élite morisca en la Granada Cristiana. El ejemplo de la familia Hermes", en Mélanges Louis Cardaillac, Zagohuan, Fundación Temini, 1995, vol. 2, pp. 649-658.

Soria Mesa, Enrique, "Entre reyes moros y oscuros labradores cristianos. Un itinerario familiar morisco: los Granada Venegas de Monachíl (ss. XVI-XVIII)", en Manuel Titos Martínez (ed.), Monachil, Historia de un pueblo de la Sierra, Monachíl, Excmo. Ayuntamiento de Monachíl, 1995, pp. 159-182.

Soria Mesa, Enrique, Los últimos moriscos. Pervivencias de la población de origen islámico en el reino de Granada (s.XVII-XVIII), Valencia, Universidad de Valencia, 2014.

Varo Zafra, Juan, "Carta de don Diego Hurtado de Mendoza al Cardenal Espinosa sobre la Guerra de Granada”, Manuscrt.Cao, 12 (2012), 20 pp.

Vega García-Ferrer, María Julieta, Fray Hernando de Talavera y Granada, Granada, Universidad de Granada, 2007.

Vincent, Bernard, El río Morisco, Valencia, Publicaciones de la Universidad de Valencia, Universidad de Granada, Universidad de Zaragoza, 2006, col. Biblioteca de estudios moriscos. 